Page 1 of

Proj.
ECN

2. ECN Category (mark one)
Supplemental
Direct Revision
Change ECN
Temporary
Standby
Supersedure
CancelNoid

12a. Modification Work

$\square$ Yes (fill out Blk. 12b)

$\bigotimes$ No (NA Blks. 12b 12c, 12d)

3. Originator's Name, Organization, MSIN, and Telephone No.

K. D. Fowler, Process Engineering, 74B00

4. USQ Required? 5. Date

R2-11, 373-5930

\begin{tabular}{|l|l|l}
\hline 6. Project Title/No.Nork Order No. & 7. Bldg./Sys./Fac. No. & 8. Approval Designator
\end{tabular}

TE Waste Transfer Compatibility

Program

9. Document Numbers Changed by this ECN (includes sheet no. and rev.)

HNE-SD-WM-OCD-015, Rev, 2

10. Related ECN No(s).

ES

\begin{tabular}{|l|l|l|l}
\hline 12b. Work Package No. & 12c. Modification Work Completed & 12d. Restored to Original Condition (Temp.
\end{tabular}

NA

NA or Standby ECNs only)

NA

Design Authority/Cog. Engineer Signature \& Date

Design Authority/Cog. Engineer Signature \&

13a. Description of Change 13b. Design Baseline Document? $\square$ Yes $\square$ No

Total Revision for compliance with current Tank Rarms acceptance requirements.

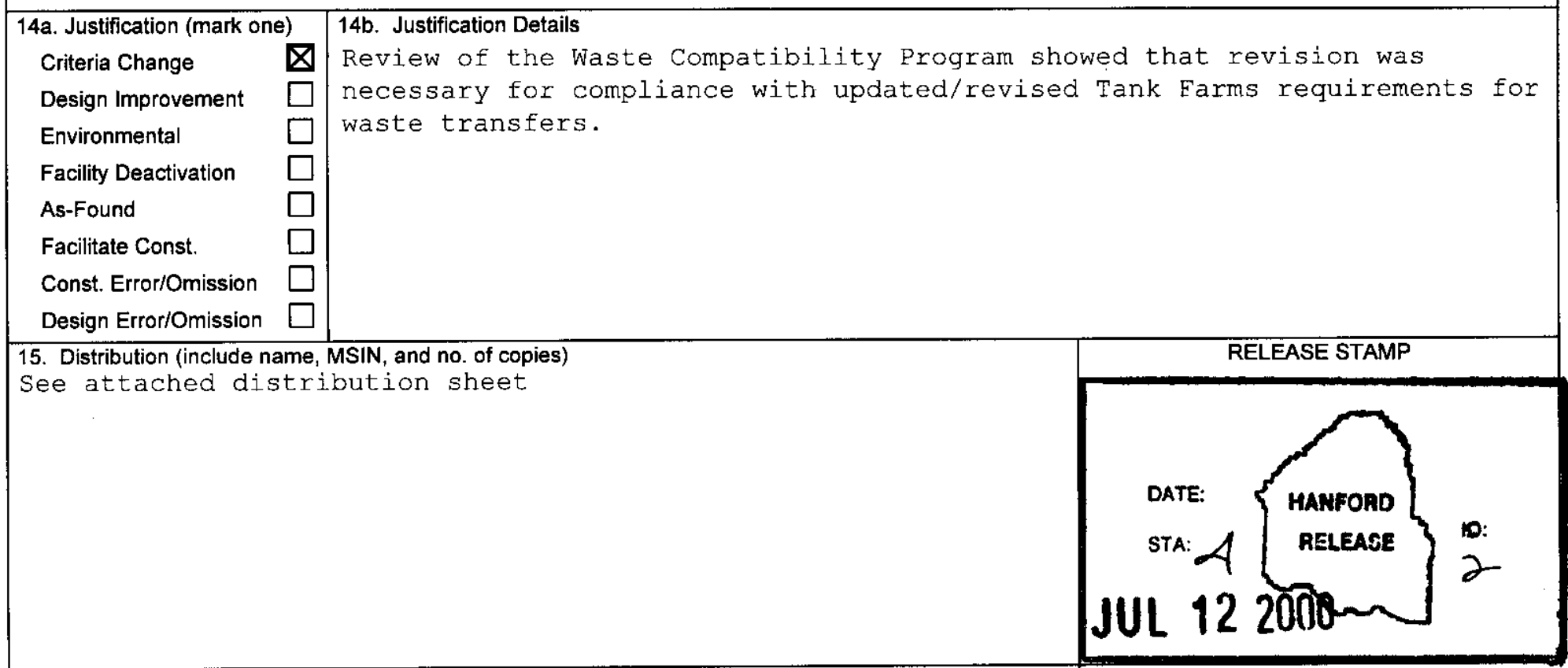




\section{ENGINEERING CHANGE NOTICE}

16. Design Verification Required

$\square$ Yes

17. Cost Impact

ENGINEERING

Additional $\square \quad \$$
Savings $\square \$ \$$

\section{CONSTRUCTION}

Additional $\square \$$
Savings $\square \$$
1. ECN (use no. from pg. 1)

657005

18. Schedule Impact (days)

Improvement

Delay

19. Change Impact Review: Indicate the related documents (other than the engineering documents identified on Side 1) that will be affected by the change described in Block 13. Enter the affected document number in Block 20.

SDD/DD

Functional Design Criteria

Operating Specification

Criticality Specification

Conceptual Design Report

Equipment Spec.

Const. Spec.

Procurement Spec.

Vendor Information

OM Manual

FSAR/SAR

Safety Equipment List

Radiation Work Permit

Environmental Impact Statement

Environmental Report

Environmental Permit
Seismic/Stress Analysis

Stress/Design Report

Interface Control Drawing

Calibration Procedure

Installation Procedure

Maintenance Procedure

Engineering Procedure

Operating Instruction

Operating Procedure

Operational Safety Requirement

IEFD Drawing

Cell Arrangement Drawing

Essential Material Specification

Fac. Proc. Samp. Schedule

Inspection Plan

Inventory Adjustment Request
Tank Calibration Manual Health Physics Procedure

Spares Multiple Unit Listing

Test Procedures/Specification

Component Index

ASME Coded Item

Human Factor Consideration

Computer Software

Electric Circuit Schedule

ICRS Procedure

Process Control Manual/Plan

Process Flow Chart

Purchase Requisition

Tickler File

None

\section{None}

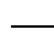

20. Other Affected Documents: (NOTE: Documents listed below will not be revised by this ECN.) Signatures below indicate that the signing organization has been notified of other affected documents listed below.

\section{Approvals}

Design Authority

Cog. Eng. K. D. Eowler

QA

Safety

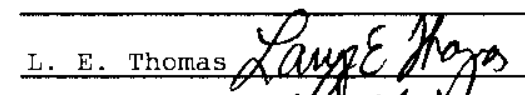

Environ. C. H. Mulkey

Other

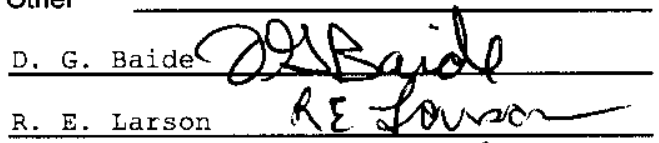

T.M. BLAAK Zoreslars

NN DNELER

$\frac{7 / 11 / 00}{7 / 11 / 00}$

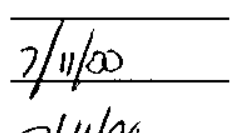

$2 / 4104$

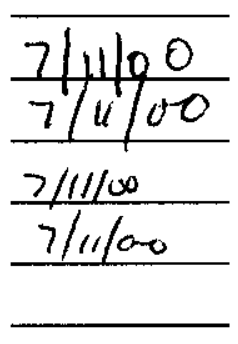

Design Agent

PE

QA

Safety

Design

Environ.

Other

\section{DEPARTMENT OF ENERGY}

Signature or a Control Number that tracks the Approval Signature

\section{ADDITIONAL}




\title{
Tank Farm Waste Transfer Compatibility Program
}

K. D. Fowler

CH2M Hill Hanford Group

Richland, WA 99352

U.S. Department of Energy Contract DE-AC06-96RL13200

\author{
EDT/ECN: $657005 \quad$ UC: 2070 \\ Org Code: 74B00 Charge Code: 112976 \\ B\&R Code: EW3120074 Total Pages: 33
}

Key Words: Compatibility, Transfer, Waste Transfer, Compatibility Program

\begin{abstract}
The compatibility program described in this document formalizes the process for determining waste compatibility. The promary goal of the program is to ensure that sufficient controls are in place to prevent the formation of incompatible mixtures during future operations. The porcess described involves characterizing waste, comparing characteristics with criteria, resolving potential incompatibilities and documenting the process.
\end{abstract}

TRADEMARK DISCLAIMER. Reference herein to any specific commercial product, process, or service by trade name, trademark, manufacturer, or othenwise, does not necessarily constitute or imply its endorsement, recommendation, or favoring by the United States Government or any agency thereof or its contractors or subcontractors.

Printed in the United States of America. To obtain copies of this document, contact: Document Control Services, P.O. Box 950, Mailstop H6-08, Richland WA 99352, Phone (509) 372-2420; Fax (509) 376-4989.
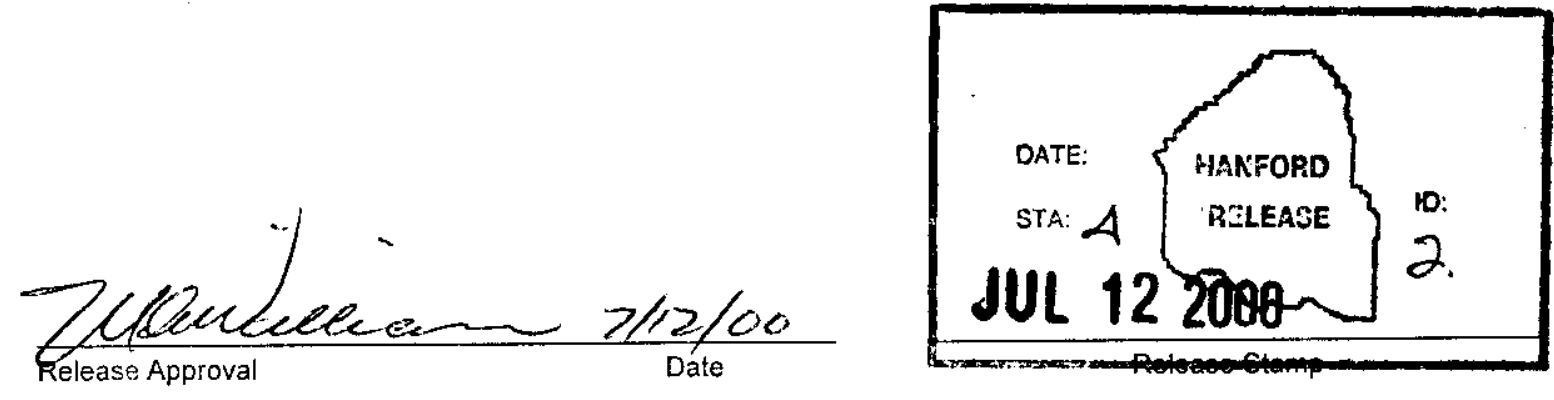

\section{Approved For Public Release}




\section{RECORD OF REVISION}

(2) Title

Tank Farm Waste Transfer Compatibility Program.

Change Control Record

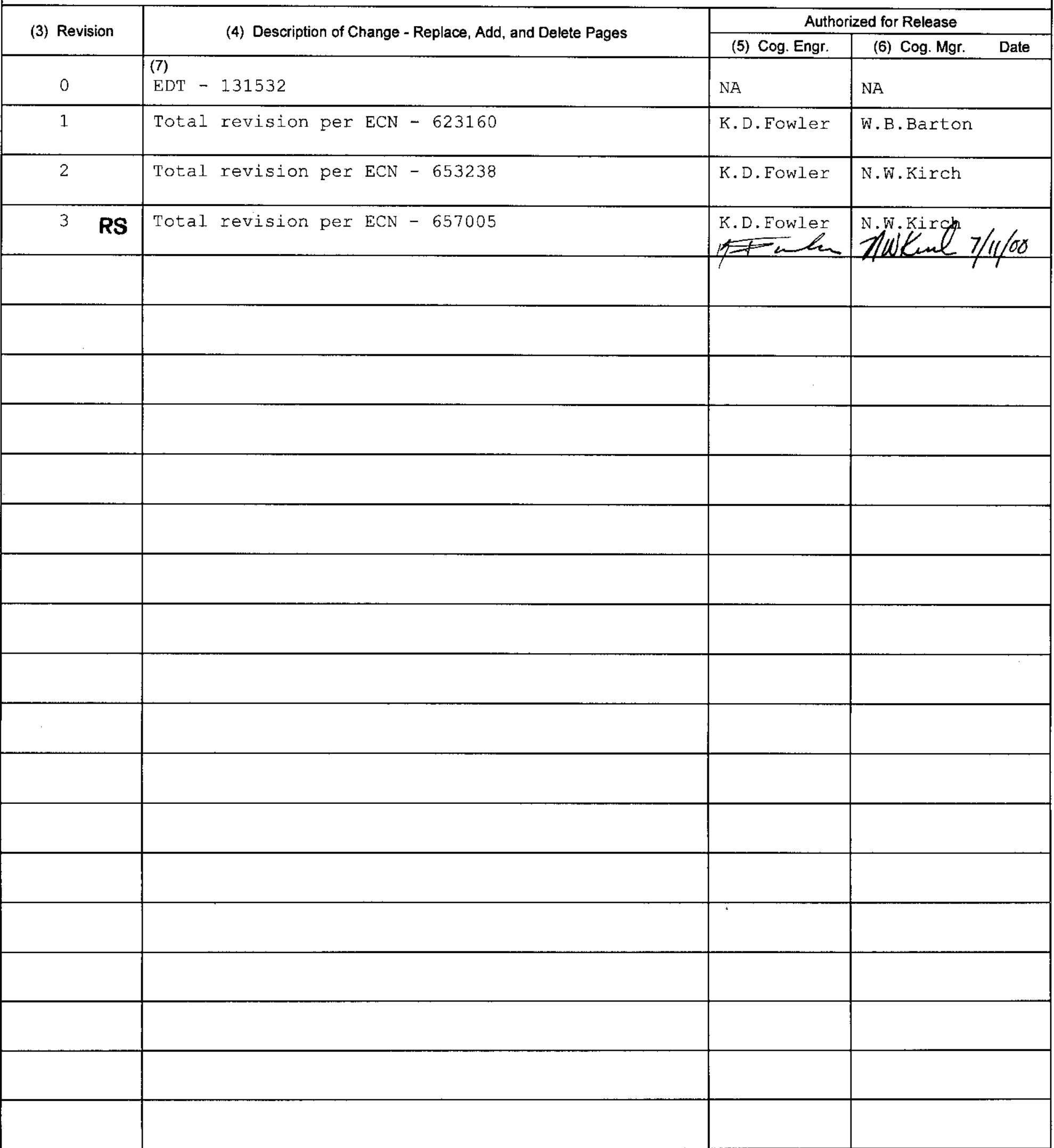




\section{HNF-SD-WM-OCD-015, Rev. 3}

\section{TABLE OF CONTENTS}

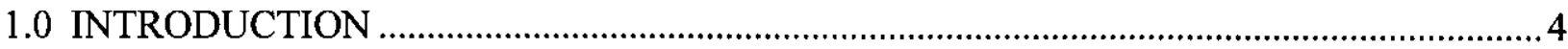

1.1 PURPOSE

1.2 SCOPE

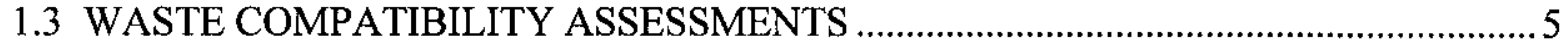

1.3.1 Documentation .................................................................................................

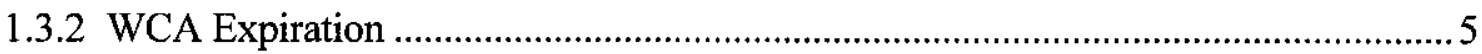

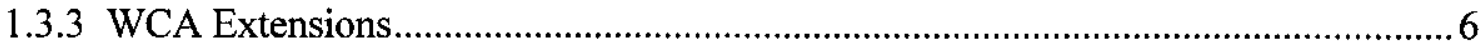

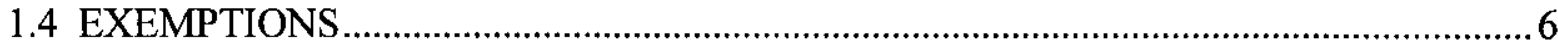

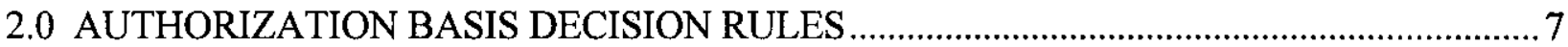

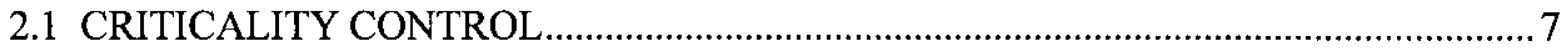

2.1.1 Transfers from non-Tank Farm facilities.........................................................

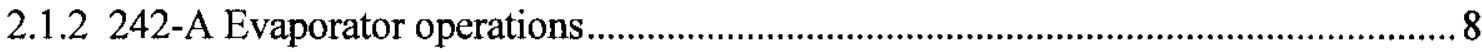

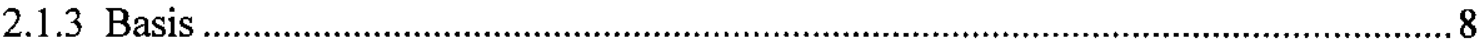

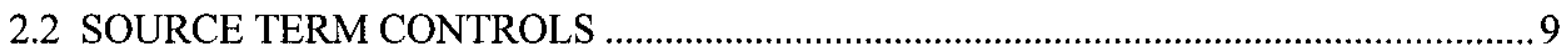

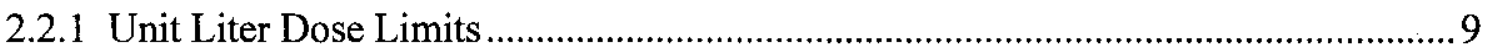

2.2.2 Total Fraction of Risk Guide Limits................................................................... 10

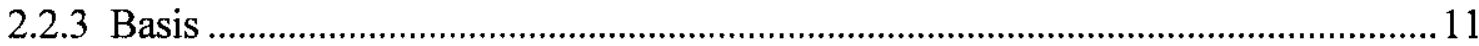

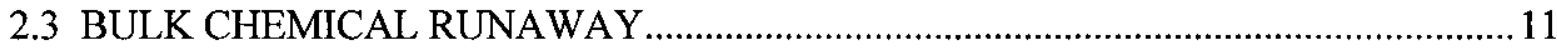

2.3.1 Bulk Chemical Runaway Reaction................................................................... 11

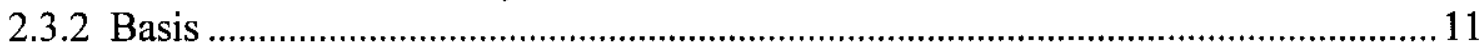

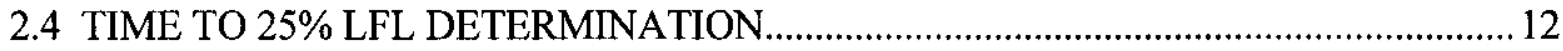

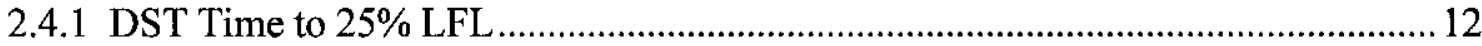

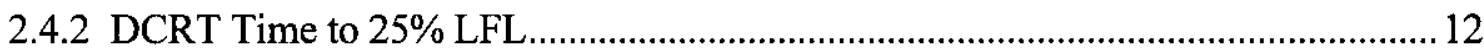

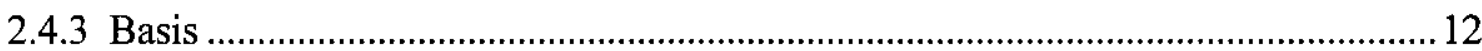

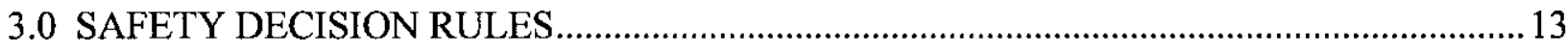

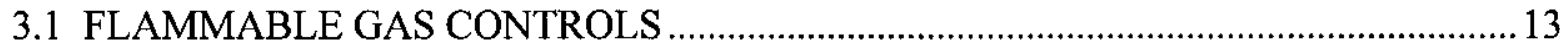

3.1.1 Flammable Gas Generation/Retention ................................................................ 13

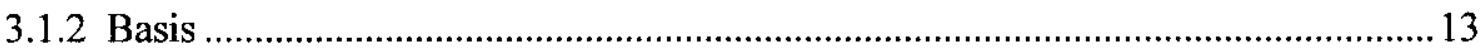

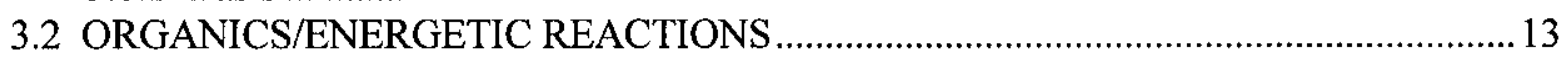

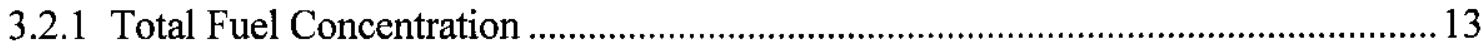

3.2.2 Separable Organic Material ............................................................................ 14

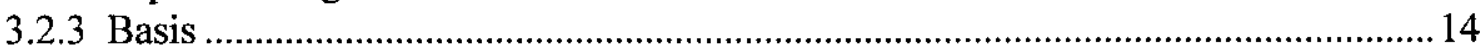

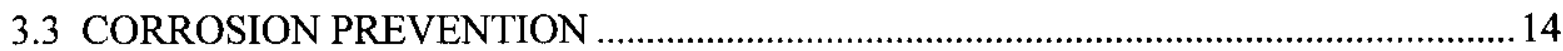

3.3.1 DST System Corrosion Prevention Controls ............................................................. 14

3.3.2 DST and DCRT Tank Composition Limits ………...............................................15

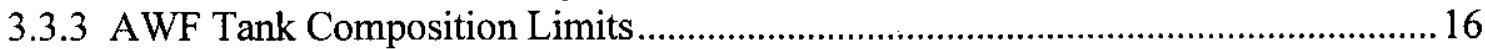

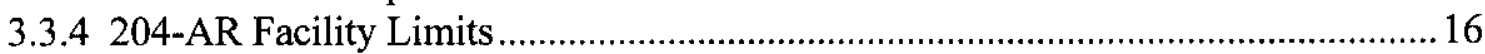

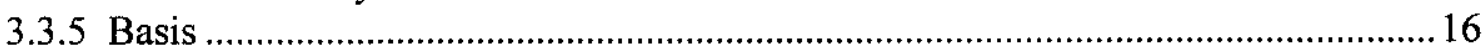

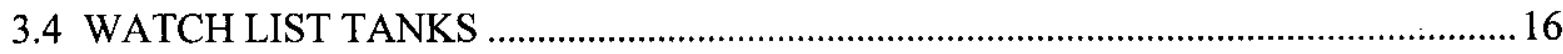

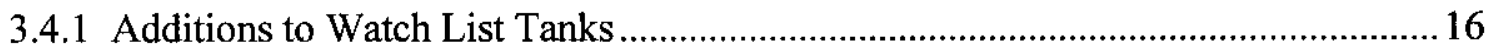

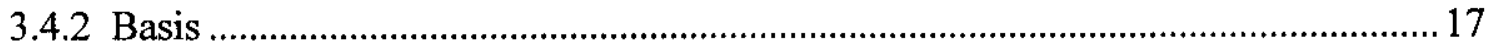

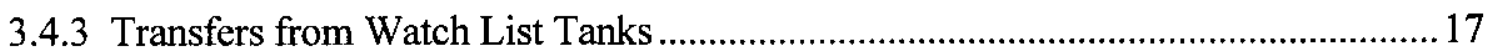

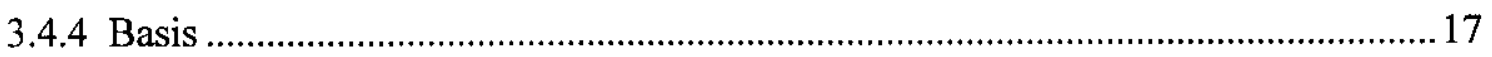




\section{HNF-SD-WM-OCD-015, Rev. 3}

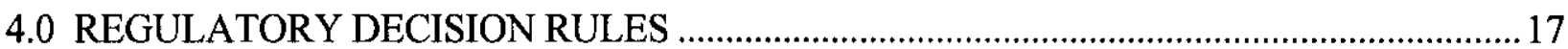

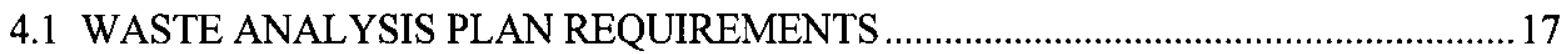

4.1.1 Waste Stream Profile Sheet .................................................................................... 17

4.1.2 Waste Reactivity Group ..................................................................................... 19

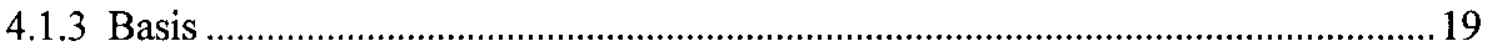

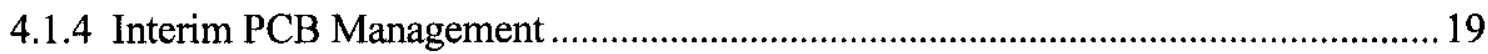

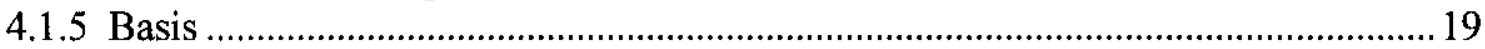

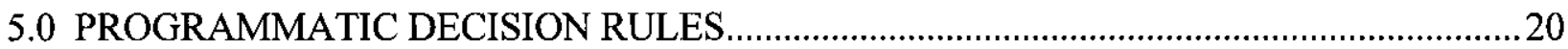

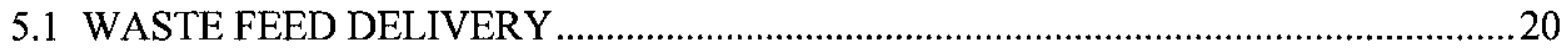

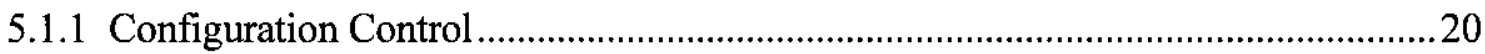

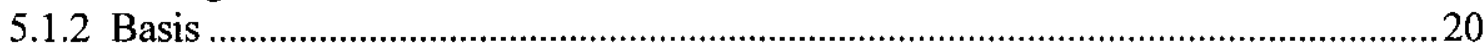

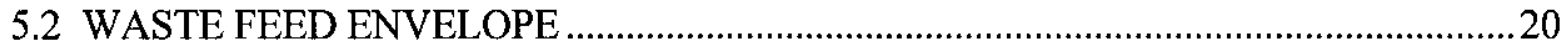

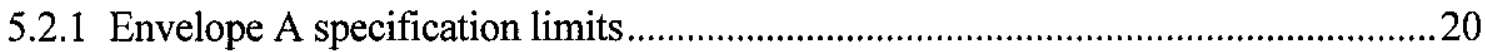

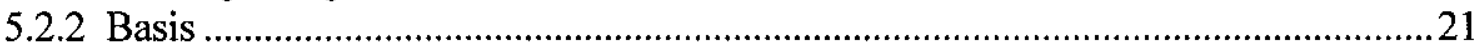

5.3 WASTE INVENTORY CONTROL GROUP APPROVAL ……………………..............21

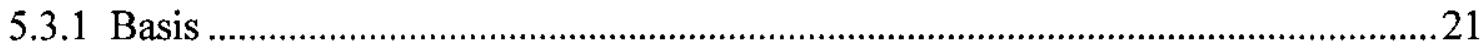

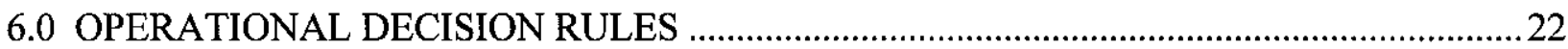

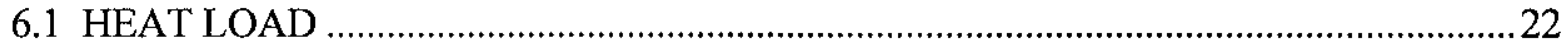

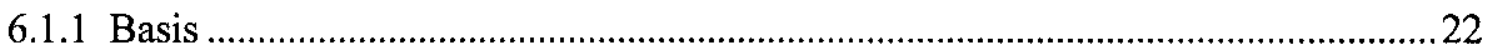

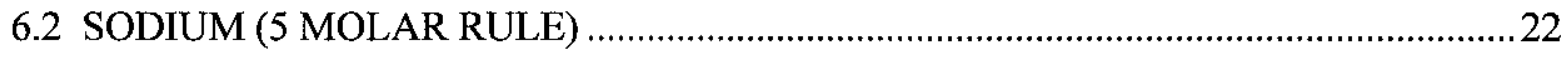

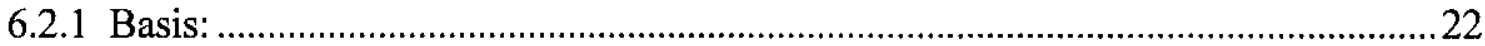

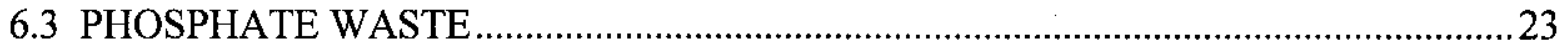

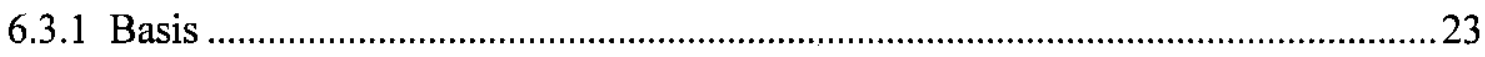

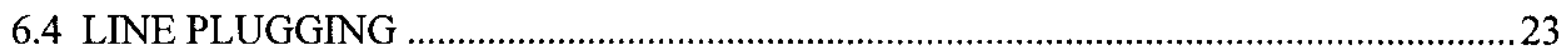

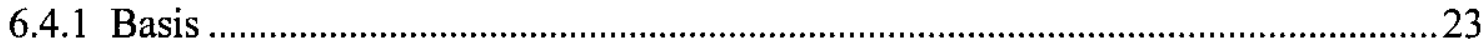

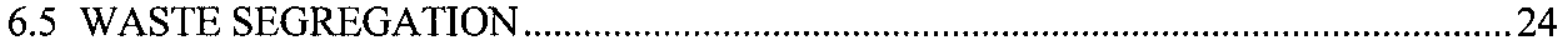

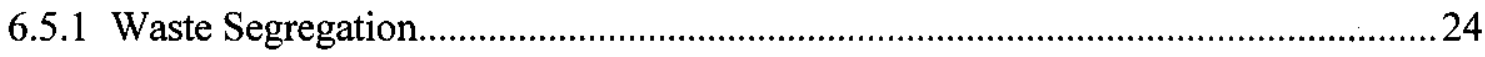

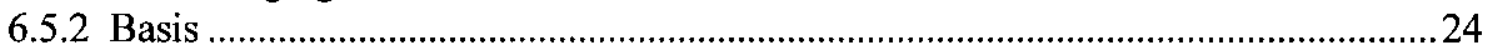

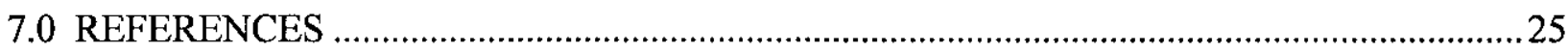




\section{LIST OF TERMS}

$\begin{array}{ll}\text { AWF } & \text { Aging waste facility } \\ \text { Bq } & \text { Becquerel } \\ \text { Btu } & \text { British thermal unit } \\ \text { CC } & \text { concentrated complexed waste } \\ \text { CPS } & \text { Criticality Prevention Specification } \\ \text { CSER } & \text { Criticality Safety Evaluation Report (Rogers 1994) } \\ \text { DC } & \text { dilute complexed waste } \\ \text { DCRT } & \text { double-contained receiver tank } \\ \text { DOE } & \text { U. S. Department of Energy } \\ \text { DSSF } & \text { double-shell slurry feed } \\ \text { DST } & \text { double-shell tank } \\ \text { EDCF } & \text { effective dose conversion factor } \\ \text { EPA } & \text { U.S. Environmental Protection Agency } \\ \text { FRG } & \text { fraction of risk guide } \\ \text { LFL } & \text { lower flammability limit } \\ \text { NCRW } & \text { neutralized cladding removal waste } \\ \text { ORP } & \text { Office of River Protection } \\ \text { PCB } & \text { Polychlorinated biphenyl } \\ \text { RPP } & \text { River Protection Project (formerly TWRS) } \\ \text { SpG } & \text { specific gravity } \\ \text { SST } & \text { Single-shell tank } \\ \text { TA } & \text { total alpha (analysis) } \\ \text { TFRG } & \text { total fraction of risk guide } \\ \text { TOC } & \text { total organic carbon } \\ \text { TRU } & \text { transuranic } \\ \text { TT LFL } & \text { Time to 25\% LFL determination } \\ \text { ULD } & \text { unit liter dose } \\ \text { WAP } & \text { Double-Shell Tank Waste Analysis Plan (Mulkey 1998) } \\ \text { WCA } & \text { waste compatibility assessment } \\ \text { WFD } & \text { Waste Feed Delivery } \\ \text { WSPS } & \text { Waste Stream Profile Sheet } \\ & \end{array}$




\subsection{INTRODUCTION}

Mixed wastes are stored at the Hanford site on an interim basis until they can be treated, as necessary, for final disposal. The Tank Farm Waste Transfer Compatibility Program is implemented to help assure continued safe and prudent storage and handling of these wastes.

This document describes decision rules relating to waste transfers both into and within the Hanford Site Double-Shell Tank (DST) Farm System. It defines a consistent means of applying safety, operational, regulatory and programmatic criteria and specifies considerations necessary to assess waste transfers.

\subsection{PURPOSE}

This document specifies decision rules for waste transfers within and for the receipt of waste into Tank Farms DST System ${ }^{1}$. Only Tank Farm requirements and limits affected by the transfer or receipt of waste are addressed.

Requirements for tank piping, leak detection and ventilation systems have been omitted from this document because continual monitoring is generally required for systems in use. Operation of these systems is controlled by other administrative procedures and control documents. For similar reasons, effluent emission limits, concrete temperature limits and physical system requirements for waste transfer (e.g., transfer routing, line testing, etc.) also have been omitted.

For each compatibility issue the 'Basis' section(s) contains the technical basis for the decision rule(s), or the reference document(s) that contains the technical basis for the rule(s).

\subsection{SCOPE}

The decision rules of this document apply to all waste transfers except as specified in Section 1.4 (Exemptions) of this document. The operations encompassed include:

1) combining the wastes within the DST System,

2) transferring waste between the tanks and the 242-A Evaporator,

3) receiving waste from Tank Farms facilities outside of the DST System and

4) receiving waste from non-Tank Farms Facilities.

In general, the decision rules for DSTs apply to all of the DSTs. The only exception is where a certain $\operatorname{tank}(\mathrm{s})$, is (are) specifically excluded, or a separate decision rule governing the same parameter(s) is given for specific a $\operatorname{tank}(\mathrm{s})$.

Decision rules written for single-shell tanks (SSTs) apply to all SSTs .

${ }^{1}$ The definition of DST System is taken from the DST Part B Permit in the Double-Shell Tank Waste Analysis Plan 


\subsection{WASTE COMPATIBILITY ASSESSMENTS}

As required by HNF-IP-1266, Section 5.12, Transfer Controls, prior to acceptance of a waste transfer, the proposed transfer shall be evaluated as specified in this document. The evaluation is necessary to ensure that the sending and receiving tanks will still meet the controls for criticality (Section 2.1), tank bumps (Section 6.1), flammable gas deflagrations (Section 2.4), organic solvent fires (Section 3.2), organic saltnitrate reaction (Section 3.2), and bulk chemical runaway (Section 2.3) after the transfer. The waste compatibility assessment (WCA) will compare compositions of the proposed waste source(s), waste receiver(s), and transfer conditions to the decision rules given in Sections 2 through 6 of this document.

\subsubsection{Documentation}

If it is determined, via the WCA, that a proposed transfer is acceptable, the WCA is documented along with a recommendation for proceeding with the proposed waste transfer. The documented WCA is signed by Double-Shell Tank Farms Engineering or Single-Shell Tank Farms Engineering, Process Engineering and Environmental Services before it is issued. In addition, for waste transfers from non-Tank Farm facilities, the WCA must be signed/initialed by the RPP Criticality Safety Representative (CSR) to verify compliance with criticality prevention limits. Assessment documentation shall include, as a minimum, disposition of each applicable decision rule as listed in the Compatibility Compliance Table (Appendix A), transfer requirements (if any) and WCA expiration date (see 1.3.2 below).

If it is determined that a proposed transfer is not acceptable the WCA may be issued to formally document issues of non-compliance.

\subsubsection{WCA Expiration}

River Protection Project (RPP) requirements which affect waste compatibility may change over time. To assure that ongoing transfers are periodically reviewed for compliance with the most recent requirements and consider current tank conditions expiration dates are established for each assessment.

The expiration date established for assessments shall consider the following guidelines:

- $\quad$ Each WCA shall expire in a time period not to exceed 1 year from issuance.

- Assessments for the receipt of waste into the DST System shall expire before or upon expiration of the waste stream profile sheet (WSPS) used to complete the assessment.

- Assessments for one-time transfers shall expire upon completion of the transfer and any associated transfer line flushing. 


\subsubsection{WCA Extensions}

A written extension of up to 1 year may be issued for an expired WCA. However, there is no provision for extending an expired WSPS. To issue a WCA extension, each of the following conditions must be met:

1) The source waste stream must have a current WSPS on file (non-DST System generators only).

2) Review of current transfer conditions shows no adverse changes to compliance status of previously assessed WCA issues.

3) All current WCA compliance issues are addressed in the original WCA or in the extension documentation.

4) Concurrence is obtained from Double-Shell Tank Farms Engineering or Single-Shell Tank Farms Engineering, Process Engineering and Environmental Services.

\subsection{EXEMPTIONS}

Certain additions to waste tanks are unlikely to cause any waste compatibility problems. This type of addition may occur on a regular basis, thus, conducting waste compatibility assessments each time is neither feasible nor technically justified.

Water or condensate used to pressure test waste transfer pipelines is one example of such an addition. The water used in a pressure test drains back into waste tanks where it mixes with the stored waste. Because liquid tank wastes are aqueous solutions and slurries of inorganic salts contaminated with minor amounts of radionuclides and organic salts, water additions serve only to dilute the waste and, in most cases, reduce interactions between compounds in the waste.

Therefore, the following types of additions to DSTs are exempt from waste compatibility assessments (see note below).

- Potentially contaminated water (e.g., cooling water, rain water, snow melt, pipeline flush water, pipeline pressure test water, deentrainer flush water, airlift circulator flush water) with no chemicals added except for those required for tank corrosion control (i.e., sodium hydroxide and sodium nitrite).

- Small volumes (i.e., $\leq 0.25 \%$ of the existing receiver tank waste volume) of essentially organicfree aqueous Tank Farm facility waste containing only any of the major inorganic sodium salts (i.e., aluminate, nitrate, nitrite, carbonate, sulfate, phosphate, fluoride and chloride), sodium hydroxide, trace metals, or radionuclides.

Note: Though exempt from compatibility assessments, the exempt additions described above must comply with the Authorization Basis and Safety decision rules in Sections 2 and 3 of this document. To verify compliance, with Section 2 and 3 decision rules, exempt additions will require written concurrence from Process Engineering and Environmental Services. 


\subsection{AUTHORIZATION BASIS DECISION RULES}

\subsection{CRITICALITY CONTROL}

Fissile materials of concern are ${ }^{239} \mathrm{Pu},{ }^{233} \mathrm{U}$ and ${ }^{235} \mathrm{U}$. Limits are stated for Pu equivalents. One gram of ${ }^{235} \mathrm{U}$ in excess of $0.72 \mathrm{wt} . \%$ enrichment, one gram of ${ }^{233} \mathrm{U}$, and each gram of ${ }^{239} \mathrm{Pu}$ shall be equivalent to one gram of plutonium, unless otherwise restricted by a specification.

\subsubsection{Transfers from non-Tank Farm facilities}

Waste transfers into the DST system from non-Tank Farm facilities must comply with the following criticality prevention limits or a criticality safety evaluation must be completed documenting that the waste may be stored safely in the DST system.

Minimum pH: $\quad 28.0$

Additions of non-fissile material bearing solution as specified in LMHC 1998a (CPS-T-149-00010, General Limits, Section 5) are allowed without pH control.

Maximum Pu concentration: $\quad<0.033 \mathrm{~g} / \mathrm{l}$

Maximum $\mathrm{Pu}$ concentration without

considering absorber/Pu ratio: $\quad \leq 0.001 \mathrm{~g} / \mathrm{l}$

Minimum absorber/Pu mass ratios are specified in Table 2-1

Table 2-1. Minimum Absorber/Pu Mass Ratios

\begin{tabular}{|c|c|}
\hline Neutron Absorber $(X)$ & $\begin{array}{l}\text { Minimum Neutron Absorber/D } \\
\text { Subcritcal Mass Rato (APu) }\end{array}$ \\
\hline Total Uranium (U) & 770 \\
\hline Iron $(\mathrm{Fe})$ & 160 \\
\hline Manganese (Mn) & 32 \\
\hline Nickel (Ni) & 105 \\
\hline Chromium (Cr) & 135 \\
\hline
\end{tabular}

If the $\mathrm{Pu}$ content of a single waste batch exceeds $50 \mathrm{~g}$, the sum of component subcritical mass fractions shall be $z 2$.

The sum of subcritical mass fractions is calculated by summing the division of the actual mass of absorber to fissile material to the subcritical mass of absorber.

i.e., $[(\mathrm{U} / \mathrm{Pu})$ actual/(U/Pu)subcritical $]+[(\mathrm{Cr} / \mathrm{Pu})$ actual $/(\mathrm{Cr} / \mathrm{Pu})$ subcritical $]+$ $[(\mathrm{Fe} / \mathrm{Pu})$ actual $/(\mathrm{Fe} / \mathrm{Pu})$ subcritical $)]+\ldots>2$ 
Requirements on $\mathrm{pH}, \mathrm{Pu}$ concentration and subcritical mass ratio of neutron absorbers to $\mathrm{Pu}$ do not apply to transfers made between Tank Farm facilities or to transfers from the 242-A Evaporator facility during an evaporation campaign.

\subsubsection{2-A Evaporator operations}

Transfers involving waste staging for 242-A Evaporator feed shall meet the following limit:

$$
\text { Pu concentration in feed: } \quad<0.005 \mathrm{~g} / 1(0.019 \mathrm{~g} / \mathrm{gal})
$$

For 242-A Evaporator waste, Pu equivalents may be calculated from total $U$ as follows when isotopic analysis is not available:

$$
\mathrm{Pu} \text { equivalents }=\text { Total } \mathrm{U} *(0.82 \%-0.72 \%)
$$

\subsubsection{Basis}

All of the waste streams that were sent to the Hanford Site underground waste tanks contained only small amounts of $\mathrm{Pu}$. Furthermore, the concentrations of various neutron absorbers in the waste streams were consistently high. A team of senior technical personnel has reviewed the technical basis for the nuclear criticality safety of waste stored in Hanford underground tanks. The team concluded that, under current $\mathrm{Pu}$ inventories and operating conditions, a nuclear criticality accident is not credible in any Hanford Site SST, DST, catch tank or double-contained receiver tank (DCRT) (Bratzel, et al., 1996).

The DST system is classified as a "Limited Control" facility (Cox, et al. 1997). This classification is based on the DST system containing a fissile material inventory in excess of 177 grams (one third of a minimum critical mass) and an evaluation that demonstrates that a criticality is prevented by the form and distribution of the fissile material. Wastes are discharged from generating facilities with a low concentration of $\mathrm{Pu}$ and a high ratio of solids as necessary to ensure a high degree of subcriticality. The alkalinity of waste streams is maintained high to ensure insolubility of $\mathrm{Pu}$ and waste solids.

Prior to acceptance into the DST system, each waste stream is assessed for compatibility with the waste in the receiving tank. The $\mathrm{pH}, \mathrm{Pu}$ concentration and the absorber-to-Pu ratio (as required) are evaluated against criticality prevention limits (LMHC 1998a). Compliance with the Criticality Prevention Specification (CPS) assures that the form and distribution of fissile material in the receiving tank is consistent with the basis for the facility classification.

$\mathrm{Pu}$ that will be discharged to the DST system will have been subjected to acid dissolution followed by caustic coprecipitation with heavy metal neutron absorbers. As a result of the processing, the $\mathrm{Pu}$ and neutron absorbers formed agglomerates with subcritical mass ratios. For waste from the Plutonium Finishing Plant, iron was added to the waste to ensure dilution of Pu in the solids.

Submicron particle size is an important result of the acid dilution and caustic precipitation process. The small particle size limits segregation of Pu in the DST system caused by differences in settling velocities. 
The composition of each waste stream entering the DST system is documented on a Waste Stream Profile Sheet (WSPS) as required by the DST Waste Analysis Plan (Mulkey 1998). The bounding values from the WSPS are used to assess waste compatibility. Prior to discharge into the DST system, each new or revised WSPS from non-Tank Farms waste generators is reviewed by Criticality Safety Personnel (see Section 4.1.1). The review is necessary to ensure that the composition of the waste stream is/remains in compliance with the boundaries of the evaluation established in the Criticality Safety Evaluation Report (CSER) (Rogers 1994).

\subsection{SOURCE TERM CONTROLS}

\subsubsection{Unit Liter Dose Limits}

For transfers from non-Tank Farm facilities, Engineering shall review generator provided data to assure unit liter dose (ULD) values do not exceed the values in the following tables. Instructions for completing both Table 2-2 and Table 2-3 are given below.

\begin{tabular}{|l|l|l|l|l|}
\hline \multicolumn{7}{|c|}{ Contribution of S Radionuclides to ULD for Inhalation } \\
\hline
\end{tabular}

\begin{tabular}{|c|c|c|c|c|c|c|c|c|}
\hline \multicolumn{9}{|c|}{\begin{tabular}{|c|} 
\\
Contribution of 5 Radionuclides to ULD for Ingestion, Ground Shine and Resuspension
\end{tabular}} \\
\hline \multirow[b]{2}{*}{ Isotope } & \multicolumn{4}{|c|}{\begin{tabular}{|c|} 
AWF DST Liquids \\
\end{tabular}} & \multicolumn{4}{|c|}{$\begin{array}{c}\text { Incoming Waste Liquids } \\
\end{array}$} \\
\hline & Conc & IDCF & UI.D & $\%$ UID & (A) conc & (B) $\mathrm{EDCF}$ & (C) ULD & (D) $\%$ UI.D \\
\hline & $\mathrm{Bq} / 1$ & $\mathrm{~Sv} / \mathrm{Bq}$ & $\mathrm{Sv} / \mathrm{I}$ & & $\mathrm{Bq} / \mathrm{l}$ & Sv/bq & $\mathrm{Sv} / \mathrm{l}$ & \\
\hline $\operatorname{Sr} 90$ & $4.59 \mathrm{E}+09$ & $2.14 \mathrm{l}-12$ & $1.00 \mathrm{E}-02$ & 15.6 & & $2.14 \mathrm{E}-12$ & & \\
\hline Y 90 & $4.59 \mathrm{E}+09$ & $1.96 \mathrm{E}-13$ & $9.101:-04$ & 1.42 & & $1.96 \mathrm{E}-13$ & & \\
\hline Cs 137 & $5.86 \mathrm{E}+10$ & $8.82 E-13$ & $5.30 \mathrm{E}-02$ & 82.68 & & $8.82 \mathrm{E}-13$ & & \\
\hline Pu 239 & $1.20 \mathrm{E}+06$ & $6.75 \mathrm{E}-11$ & $8.10 \mathrm{E}-05$ & 0.13 & & $6.75 \mathrm{E}-11$ & & \\
\hline $\operatorname{\Lambda m} 241$ & $1.101 \div+06$ & $6.91 \mathrm{E}-11$ & $7.60 \mathrm{E}-05$ & 0.12 & & $6.915:-11$ & & \\
\hline Total ULD & & & $6.411:-02$ & 99.98 & & & & \\
\hline
\end{tabular}


Instructions for Table 2-2 and Table 2-3:

Complete for both tables

1. Enter generator provided analyses data in the appropriate row of column (A)

2. Multiply column (A) concentration values by column (B) effective dose conversion factors ( $\mathrm{HI}) \mathrm{CF}$ ) and enter the product in appropriate row of column (C) UI,D.

3. Once all individual ULDS are calculated and entered, divide each individual UI,D, column (C), by the total UIDS $(1.12 \mathrm{E}+03$ or $6.41 \mathrm{E}-02)$ and multiply by 100 to find the percent contribution of the incoming waste towards the total bounding ULD. Enter percent value in appropriate row of column (D).

4. If the percent of the ULD for each isotope (column (D)) in the incoming waste is $\leq$ the corresponding "\% of ULD" the waste may be transferred.

5. If any of the isotope percentages in column (D) is $\geq$ the corresponding "\% of ULD" then add the values in column (D) to calculate the total percentage. If the total percentage of column (D) is < the total of "\% of ULD" provided, the waste may be transferred.

6. If the total percent (column (D) of the incoming waste is > the total "\% of ULD" provided, engineering must complete an enginecring evaluation to determine if the source term would be violated by accepting the waste, or the waste must be adjusted by the generator to comply before transfer.

\subsubsection{Total Fraction of Risk Guide Limits}

For transfers from non-Tank Farm facilities, Lingineering shall review generator provided data to assure chemical total fraction of risk guide (TFRGs) do not exceed the values in the following table. Instructions for completing Table 2-4 are given below.

\begin{tabular}{|c|c|c|c|c|c|c|}
\hline \multicolumn{7}{|c|}{ 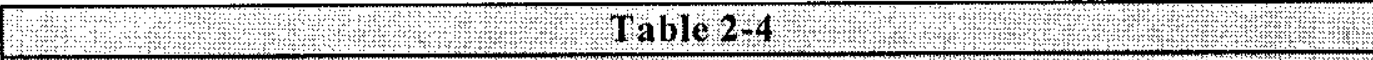 } \\
\hline & \multicolumn{6}{|c|}{ Bounding Limits for 5 analytes form DST Liquids } \\
\hline & \multicolumn{2}{|c|}{ DST Liquids } & \multicolumn{4}{|c|}{ Incoming Waste Liquids } \\
\hline Analyte & $(\Lambda) \mathrm{FRG}$ & (B) \%TFRG & (C) Conc & (D) Conversion & (E) FRG & (F) $\%$ TFRG \\
\hline & & $\mathrm{FRG}$ & $g / 1$ & lactor & & FRG \\
\hline $\mathrm{NI13}$ & 530 & 4.78 & & 74.13 & & \\
\hline $\mathrm{NaOH}$ & 3600 & 32.44 & & 17.05 & & \\
\hline $\mathrm{Na}$ & 6000 & 54.07 & & 28.42 & & \\
\hline $\mathrm{TOC}$ & 450 & 4.05 & & 11.37 & & \\
\hline $\mathrm{U}$ & 370 & 3.33 & & 34.1 & & \\
\hline Total & 11096.61 & 98.67 & & & Total & \\
\hline
\end{tabular}

Instructions for Table 2-4:

1. Enter generator provided analyses data in the appropriate row of column (C).

2. Multiply column (C) concentration values by column (D) conversion factors and enter product in appropriate row of column (E). 
3. Once all individual Fraction of Risk Guide(FRG) (column (E)) values are calculated and entered, divide each FRG (column (E)) by the total of column (A) and multiply by 100 to find the percent of Total Fraction of Risk Guide (TFRG) of the incoming waste. Enter percent value in the appropriate row of column (F).

4. If all the percentages in column (F) for the incoming waste are $\leq$ the corresponding $\%$ provided in column (B), the waste may be transferred.

5. If any of the percentages in column $(\mathrm{F})$ are ${ }_{2}$ the corresponding percentage provided for that analyte in column (B), then add the values in column (F) to calculate the total percentage. If the total percentage of column $(\mathrm{F})$ is $s$ the total percentage provided in column (B), the waste may be transferred.

6. If the total percent (column $(\mathrm{F})$ of the incoming waste is $\geq$ the total percent provided in column (B), engineering must complete an engineering evaluation to determine if the source term would be violated by accepting the waste, or the waste must be adjusted by the generator to comply before transfer.

\subsubsection{Basis}

The bases for the waste source term controls are documented in Cox, et al. 1997.

\subsection{BULK CHEMICAL RUNAWAY}

\subsubsection{Bulk Chemical Runaway Reaction}

Prior to waste transfers into the DST system, the receiving tank shall be evaluated to determine whether waste temperature controls are required to prevent a bulk chemical runaway reaction. Controls are not required if the receiving tank will meet the following conditions after transfer.

Tank heat load $<21,700 \mathrm{~W}(74,000 \mathrm{Btu} / \mathrm{hr})$

$\underline{\text { AND }}$

Total organic carbon (TOC) concentration $<52 \mathrm{~g} / \mathrm{l}(3.8 \mathrm{wt} \%)$.

Controls are also not required if a further evaluation performed per the method described in Meacham 1998 has determined that a bulk chemical runaway reaction is not possible.

\subsubsection{Basis}

The basis for bulk chemical runaway reaction is documented in Cox, et al. 1997. 
HNF-SD-WM-OCD-015, Rev. 3

\subsection{TIME TO 25\% LFL DETERMINATION}

\subsubsection{DST Time to $25 \%$ LFL}

Prior to any planned waste transfer/addition to any DST, it must be verified that the minimum time to reach $25 \%$ of the lower flammability limit (LFL) for the tank vapor space, assuming loss of the primary tank ventilation, will remain greater than 7 days, using the methodology specified in HNF-SD-WM-CN-117 (Hu, et al. 1997).

\subsubsection{DCRT Time to $25 \% \mathrm{LFL}$}

Prior to any planned waste transfer into a DCRT, it must be verified that the DCRT vapor space will remain $<25 \%$ LFL using the methodology contained in HNF-SD-WM-CN-118 (Hedengren, et al. 1997).

\subsubsection{Basis}

The bases for the DST and DCRT LFL determinations are documented in Cox, et al. 1997. 


\subsection{SAFETY DECISION RULES}

\subsection{FLAMMABLE GAS CONTROLS}

\subsubsection{Flammable Gas Generation/Retention}

For waste added to the DST system, weighted mean specific gravity $(\mathrm{SpG})$ for the commingled waste must remain $\leq 1.41$. If the weighted mean $\mathrm{SpG}>1.41$, the transfer must be evaluated on a case-by-case basis to determine the potential of the commingled waste to trap gas.

After transfer, the product of the nonconvective waste (solids) height in inches and the specific gravity of convective waste (supernate) shall remain $<148$ for the DST receiver tank. Otherwise, the transfer must be evaluated on a case-by-case basis for potential to trap gas.

The nonconvective waste height may be obtained from the most recent DST Waste Inventory from Process Engineering, Models and Inventory or from the most recent Waste Tank Summary Report (HNF-EP-0182-XXX).

\subsubsection{Basis}

The use of specific gravity to indicate gas accumulation potential in tank waste has been evaluated and there is evidence that it is an appropriate limiting factor for prevention of forming flammable gas Watch List tanks (Reynolds 1994). The six largest average specific gravity values for DST wastes are from the six DSTs on the flammable gas Watch List. The limiting specific gravity value is between 1.43 (the smallest value for a Watch List tank) and 1.40 (the largest value for a non-Watch List tank).

A statistical analysis of available specific gravity data from seven DSTs was performed to estimate the variability associated with the average specific gravity for a DST. Each tank was considered individually. The variability estimates were then used to calculate one-sided $95 \%$ confidence intervals for tank 241-AN-105 (the flammable gas Watch List DST with the smallest specific gravity). For six of the seven variability estimates ( $85 \%$ ) the lower limit of the one-sided $95 \%$ confidence interval was greater than 1.41. These results provide evidence that 1.41 is an acceptable threshold for gas accumulation.

The basis for the product of the nonconvective waste and specific gravity of convective waste is documented in Mulkey, et al. 1999.

\subsection{ORGANICS/ENERGETIC REACTIONS}

\subsubsection{Total Fuel Concentration}

Maximum Total Fuel Concentration: 480 joules/g

If free water $<20 \mathrm{wt} . \%$, TOC(dry basis) $<4.5+0.17 *$ (wt. $\%$ free water) 
Waste with any net exotherm must be evaluated for safe storage before acceptance into or transfer within the DST system.

\subsubsection{Separable Organic Material}

Separable organic waste shall require evaluation and approval on a case-by-case basis prior to acceptance for receipt into or transfer within the DST system. The evaluation shall determine whether the waste may be safely received and stored in the DST system, and other potential impacts to the DST system. As a minimum the evaluation must address

Authorization Basis compliance, regulatory impacts and RPP programmatic impacts.

Written documentation of evaluation approved by RPP Process Engineering, Environmental Services, and RPP Safety, Operations Support.

\subsubsection{Basis}

The total fuel concentration limit is set for compliance with LMHC $2000 \mathrm{~b}$ and the basis for the free water criterion is documented in Meacham 1998.

The Basis for screening out wastes with a net exotherm is documented in Mulkey, et al. 1999.

If separable organics are allowed into underground storage tanks, there is a potential that organic vapors or distillates could accumulate in the tanks, in the overhead systems, or in condensate collection tanks. An organic liquid fire or vapor explosion could result from the accumulations.

\subsection{CORROSION PREVENTION}

\subsubsection{DST System Corrosion Prevention Controls}

The receipt or transfer of waste that does not meet corrosion prevention specification limits can occur only if the receiving DST will remain within specification limits after the transfer or as part of actions for the mitigation of out-of-specification waste. Corrosion prevention limits for DSTs and for Aging Waste Facility (AWF) tanks are given in Sections 3.3.2 and 3.3.3.

Waste may be adjusted to meet DST corrosion prevention specification limits at the 204-AR Waste Unloading Facility.

Pumping of an SST whose contents do not meet corrosion prevention specification limits is permitted if analytical results from samples of that SST are used to determine what chemical additions (if any) are necessary to maintain the receiving DST and/or DCRT within corrosion prevention specification limits.

Transfers of out-of-specification waste to a DCRT shall be evaluated on a case-by-case basis. A waste transfer shall not make an in-specification DST out-of-specification. 


\subsubsection{DST and DCRT Tank Composition Limits}

For WASTE temperatures $\leq 100^{\circ} \mathrm{C}\left(212^{\circ} \mathrm{F}\right)$ :

$\underline{\text { Variable }}$

For $\left[\mathrm{NO}_{3}^{-}\right] \leq 1.0 \underline{\mathrm{M}}$ :

$\left[\mathrm{OH}^{-}\right]$

$\left[\mathrm{NO}_{2}^{-}\right]$

$\left[\mathrm{NO}_{3}^{-}\right] /\left(\left[\mathrm{OH}^{-}\right]+\left[\mathrm{NO}_{2}^{-}\right]\right)$

$\underline{\text { Specification Limit }}$

For WASTE temperatures below $75^{\circ} \mathrm{C}\left(167^{\circ} \mathrm{F}\right)$, the $\left[\mathrm{OH}^{-}\right]$limit is $8.0 \mathrm{M}$

For $1.0 \underline{\mathrm{M}}<\left[\mathrm{NO}_{3}^{-}\right] \leq 3.0 \underline{\mathrm{M}}$ :

$\left[\mathrm{OH}^{-}\right]$

$$
\begin{aligned}
& 0.1\left[\mathrm{NO}_{3}^{-}\right] \leq \mathrm{OH}^{-}<10 \underline{\mathrm{M}} \\
& \geq 0.4\left[\mathrm{NO}_{3}^{-}\right]
\end{aligned}
$$$$
\left[\mathrm{OH}^{-}\right]+\left[\mathrm{NO}_{2}^{-}\right]
$$

For $\left[\mathrm{NO}_{3}^{-}\right]>3.0 \underline{\mathrm{M}}$ :

$\left[\mathrm{OH}^{-}\right]$

$$
\begin{array}{ll}
{\left[\mathrm{OH}^{-}\right]} & 0.3 \underline{\mathrm{M}} \leq\left[\mathrm{OH}^{-}\right]<10 \underline{\mathrm{M}} \\
{\left[\mathrm{OH}^{-}\right]+\left[\mathrm{NO}_{2}^{-}\right]} & \geq 1.2 \underline{\mathrm{M}}
\end{array}
$$$$
\left[\mathrm{NO}_{3}^{-}\right] \quad \leq 5.5 \mathrm{M}
$$

For WASTE temperatures $>212^{\circ} \mathrm{F}$ in AY and AZ Farm tanks the limits of Section 3.3.2 apply except that $\left[\mathrm{OH}^{-}\right]$concentration must be $<4 \underline{\mathrm{M}}$. 


\subsubsection{AWF Tank Composition Limits}

AWF Tank Waste hydroxide $\left(\mathrm{OH}^{-}\right)$concentration (except tank 241-AZ-101 for which limits of Section 3.3.2 apply)

$$
\begin{array}{ll}
\text { For }\left[\mathrm{NO}_{3}^{-}\right] \leq 1.0 \underline{\mathrm{M}}: & \geq 0.01 \underline{\mathrm{M}} \\
\text { For } 1.0 \underline{\mathrm{M}}<\left[\mathrm{NO}_{3}^{-}\right]<3.0 \underline{\mathrm{M}}: & \geq 0.8 \underline{\mathrm{M}} \\
\text { For }\left[\mathrm{NO}_{3}^{-}\right]+\left[\mathrm{NO}_{2}^{-}\right]>5.5 \underline{\mathrm{M}}: & \geq 1.0 \underline{\mathrm{M}}
\end{array}
$$

AWF Tank Waste nitrite $\left(\mathrm{NO}_{2}{ }^{-}\right)$concentration

For $\left[\mathrm{NO}_{3}^{-}\right]$and $\left[\mathrm{OH}^{-}\right]$each $<1.0 \underline{\mathrm{M}}$ : $\quad \geq 0.011 \underline{\mathrm{M}}$

For $1.0 \underline{\mathrm{M}}<\left[\mathrm{NO}_{3}^{-}\right]<3.0 \underline{\mathrm{M}}: \quad\left[\mathrm{OH}^{-}\right]+\left[\mathrm{NO}_{2}^{-}\right] \geq 0.4 \times\left[\mathrm{NO}_{3}^{-}\right]$

For $3.0 \mathrm{M}<\left[\mathrm{NO}_{3}^{-}\right]<5.5 \underline{\mathrm{M}}: \quad\left[\mathrm{OH}^{-}\right]+\left[\mathrm{NO}_{2}^{-}\right] \geq 1.2 \underline{\mathrm{M}}$

\subsubsection{4-AR Facility Limits}

- $7<\mathrm{pH}<14\left\{10^{-7}<\left[\mathrm{OH}^{-}\right]<0.1 \underline{\mathrm{M}}\right\}$

- $\left[\mathrm{Cl}^{-}\right]<0.035 \underline{\mathrm{M}}$ (tank trailer)

\subsubsection{Basis}

The basis for the decision rules and DST corrosion prevention specification limits above is documented in Mulkey, et al. 1999 (HNF-SD-WM-DQO-001, Section 4.0) and LMHC 2000 b. The basis for the DCRT corrosion prevention specification limits is documented in LMHC 1996.

The basis for the AWF corrosion prevention specification limits is documented in LMHC $2000 \mathrm{~d}$. The basis for 204-AR Facility corrosion prevention specification limits is documented in LMHC 2000c.

\subsection{WATCH LIST TANKS}

\subsubsection{Additions to Watch List Tanks}

No additional high-level waste (except for small amounts removed and returned to a tank for analysis) shall be added to a Watch List tank unless the Secretary of the Department of Energy (DOE) determines that, (1) no safer alternative than adding such waste to the tank currently exists, or (2) that the tank does not pose a serious potential for release of highlevel nuclear waste. 


\subsubsection{Basis}

The basis for the Watch List tank restriction is Section 3137 of the National Defense Authorization Act for Fiscal Year 1991, November 5, 1990, Public Law 101-510, "Safety Measures for Waste Tanks at Hanford Nuclear Reservation" (also referred to as The Wyden Amendment).

\subsubsection{Transfers from Watch List Tanks}

Transfer of waste out of a flammable gas Watch List DST requires written approval by the Office of River Protection (ORP).

Transfer of waste out of an organic Watch List DST requires written approval by the Office of River Protection (ORP).

\subsubsection{Basis}

The basis for the Watch List tank transfer approvals is documented in LMHC 2000a.

\subsection{REGULATORY DECISION RULES}

\subsection{WASTE ANALYSIS PLAN REQUIREMENTS}

\subsubsection{Waste Stream Profile Sheet}

A completed, current Waste Stream Profile Sheet (WSPS) is required for each waste stream entering the DST system, even if there will be only a single transfer of the waste. The WSPS form can be found in the most current revision of the DST Waste Analysis Plan (WAP) (Mulkey 1998). Each WSPS shall expire 1 year from its approval date. The WSPS must be resubmitted/approved each year for ongoing transfers.

For each batch transfer into the DST system, the DST customer must provide written certification that the waste conforms to the approved information in the WSPS.

To assure the assumptions of the Tank Farms Criticality Safety Evaluation Report (Rogers 1994) are protected, each new or revised WSPS from a non-Tank Farms waste generator shall reviewed by Criticality Safety Personnel. Disposition of this compatibility compliance item shall be documented by the signature/initial of the RPP CSR or alternate on each WCA for non-Tank Farm facility transfers as specified in Section 1.3.1. This is not required for Tank Farm facility transfers. 


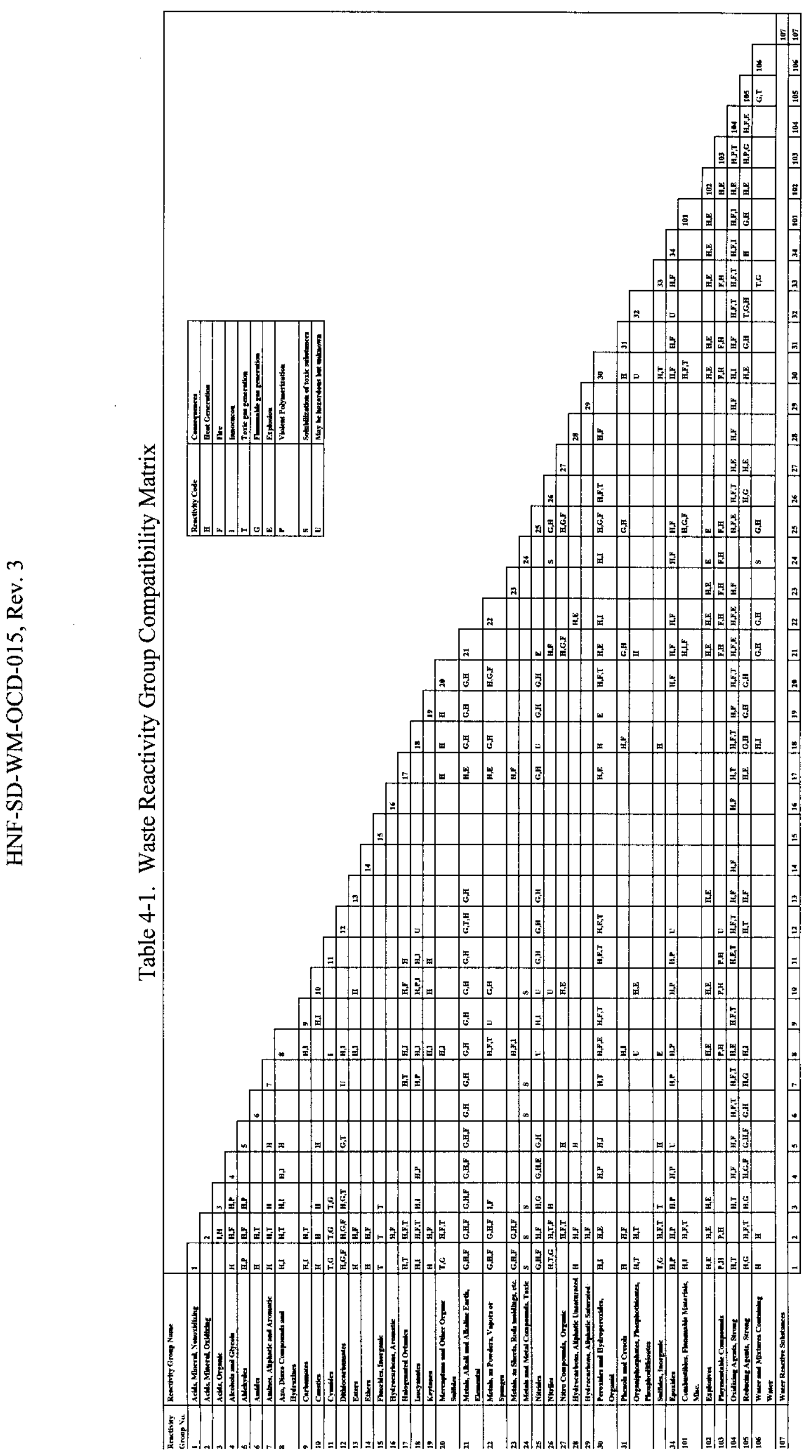




\subsubsection{Waste Reactivity Group}

Wastes entering the DST system must be categorized according to Reactivity Group (USEPA 1994) as a part of the WSPS (Section VI). The Reactivity Group numbers are used to identify potential chemical compatibility hazards prior to waste acceptance into the DST system. Source wastes shall be categorized according to Table 4-1 and potential chemical compatibility hazards identified by waste generators.

If no potential hazard is identified for mixing of wastes in the identified reactivity groups with the receiver tank waste, the transfer may be allowed.

If a potential hazard is identified, a technical justification explaining how the waste may be safely transferred and stored in light of the potential hazard will be required before allowing the transfer.

\subsubsection{Basis}

The basis for the WSPS is documented in Mulkey 1998.

\subsubsection{Interim PCB Management}

Until agreement is reached between ORP and the U.S. Environmental Protection Agency (EPA), no new external wastes containing polychlorinated biphenyls (PCBs) may be accepted into the DST system, except from 222-S Laboratory and 325 Laboratory. Waste shipments from the 222-S and 325

Laboratories are allowed, provided the waste meets the following PCB criteria:

- Waste must be characterized as non Toxic Substances Control Act (TSCA) regulated or as PCB remediation waste that does not require further treatment

- All waste imports shall be characterized for PCBs using EPA-approved methods (or an alternative procedure approved by the EPA).

- Unregulated waste containing PCBs must be supported by documentation demonstrating the PCB source, concentration at time of release, and date of release (or documentation demonstrating waste was generated prior to April 1, 1978, and currently contains $<50 \mathrm{ppm}$.

- Waste transfers exceeding $45 \mathrm{ppm}$ PCB in the solid phase or $200 \mathrm{ppb}$ in the liquid phase cannot be accepted without prior ORP approval.

\subsubsection{Basis}

The basis for interim PCB management is documented in Wood 2000. 


\subsection{PROGRAMMATIC DECISION RULES}

\subsection{WASTE FEED DELIVERY}

\subsubsection{Configuration Control}

Verify that all waste transfers involving DSTs are consistent with the restrictions given in Table 5-1.

Table 5-1. Interim Tank Usage Restrictions

\begin{tabular}{|c|c|c|c|}
\hline Feed Envelope & ISTT & Restrictions & $\begin{array}{l}\text { Static } \\
\text { Date }\end{array}$ \\
\hline \multirow{4}{*}{ A } & $241-\mathrm{AN}-103$ & No waste added/removed & $11 / 12 / 98$ \\
\hline & 241-AN-104 & No waste added/removed & $11 / 12 / 98$ \\
\hline & $241-\mathrm{AN}-105$ & No waste added/removed & $11 / 12 / 98$ \\
\hline & 241-AW-101 & No waste added/removed & $11 / 12 / 98$ \\
\hline \multirow{3}{*}{ B } & 241-AP-108 & None at this time & 2007 \\
\hline & $241-A Z-101^{1}$ & No waste added/removed & $11 / 12 / 98$ \\
\hline & $241-A Z-102^{1}$ & No waste added/removed & $11 / 12 / 98$ \\
\hline \multirow{4}{*}{$\mathrm{C}$} & 241-AN-102 & $\begin{array}{l}\text { No waste added/removed } \\
\text { Caustic addition permitted }\end{array}$ & $11 / 12 / 98$ \\
\hline & 241-AN-107 & $\begin{array}{l}\text { No waste added/removed } \\
\text { Caustic addition permitted }\end{array}$ & $11 / 12 / 98$ \\
\hline & $241-S Y-101$ & No waste added/removed & $11 / 12 / 98$ \\
\hline & $241-\mathrm{AY}-102$ & $\begin{array}{l}\text { No sludge removed. No } \\
\text { restrictions on supernate }\end{array}$ & $11 / 12 / 98$ \\
\hline
\end{tabular}

Notes:

1. Tanks contain high level Envelope D sludge

\subsubsection{Basis}

The bases for DST tank waste transfer restrictions are documented in Banning 1999.

\subsection{WASTE FEED ENVELOPE}

\subsubsection{Envelope A specification limits}

To the extent practical, retrieval and storage of liquids in DSTs shall be performed such that the stored waste meets the following limits:

The TOC in the waste is less than Envelope A specification limit, currently 0.5 moles of TOC per mole of $\mathrm{Na}$ 


\section{HNF-SD-WM-OCD-015, Rev. 3}

The concentration of $\mathrm{Sr}^{90}$ is less than the Envelope A specification limit, currently $4.4 \mathrm{E} 7 \mathrm{Becquerels}(\mathrm{Bq})$ per mole of $\mathrm{Na}$.

The concentration of TRU is less than the Envelope A specification limit, currently, $4.8 \mathrm{E} 5 \mathrm{~Bq}$ per mole of $\mathrm{Na}$.

Complexed concentrate (CC) waste should be stored with other $\mathrm{CC}$ waste if practical

\subsubsection{Basis}

The basis for feed Envelope screening is Kinzer 1998.

\subsection{WASTE INVENTORY CONTROL GROUP APPROVAL}

Transfers into and within the DST system must be approved by voting members of the DST Waste Inventory Control Group.

\subsubsection{Basis}

The basis for DST Waste Inventory Control Group Approval is documented in LMHC $1998 \mathrm{~b}$. 


\subsection{OPERATIONAL DECISION RULES}

\subsection{HEAT LOAD}

The sum of the receiving tank waste and the source waste heat generation rates (usually estimated from the mean $\mathrm{Sr}^{90}$ and $\mathrm{Cs}^{137}$ concentrations) must remain $\leq$ the limit for the receiving tank. The limits for tanks are given in Table 6-1.

Table 6-1. Tank Farm Heat Generation Rate Limits

\begin{tabular}{|c|c|}
\hline Tank Farm & Max. Ieat Gen. Rate Per Tank (Btwhr) \\
\hline $\begin{array}{l}241-\mathrm{AN} \\
241-\mathrm{AP} \\
241-\mathrm{AW}\end{array}$ & 70,000 \\
\hline $\begin{array}{l}241-\mathrm{AY} \\
241-\mathrm{AZ}\end{array}$ & $4,000,000$ \\
\hline 241-SY & 50,000 \\
\hline
\end{tabular}

\subsubsection{Basis}

The heat generation rate in tanks is limited to prevent localized boiling from occurring. The ventilating systems for the 241-AN, -AP, -AW and -SY Tank Farms were not designed for boiling, which could cause a release of contamination should it occur. The heat content limit for the 241-SY Tank Farm is based on a design criterion that is more restrictive than the point at which internal boiling occurs.

Ventilation systems for the 241-AY and -AZ Tank Farms are designed for boiling. The 4,000,000 $\mathrm{BTU} / \mathrm{hr}$ per tank limit is a maximum anticipated heat load, on which other design analyses have been based.

\subsection{SODIUM (5 MOLAR RULE)}

Maximum sodium concentration in AWF tanks

Tank 101-AZ:

Other AWF tanks:
$5.5 \mathrm{moles} / \mathrm{L}(\underline{\mathrm{M}})^{*}$

$5.0 \underline{\mathrm{M}}$

* Through concentration of wastes already stored in the tank

\subsubsection{Basis:}

The basis for the 5 molar sodium rule is documented in LMHC 2000d. 
HNF-SD-WM-OCD-015, Rev. 3

\subsection{PHOSPHATE WASTE}

Waste with a phosphate concentration, $\left[\mathrm{PO}_{4}^{-3}\right],>0.1 \mathrm{M}$, is not to be mixed with:

- waste with sodium concentration, $\left[\mathrm{Na}^{+}\right],>8 \mathrm{M}$

- neutralized cladding removal waste (NCRW).

\subsubsection{Basis}

The basis for the phosphate waste segregation rule is documented in Herting 1987; and in Herting and Patterson 1982.

\subsection{LINE PLUGGING}

For waste streams with $<5 \%$ solids by volume and $\mathrm{SpG}_{\leq} 1.35$ no evaluation is required.

For saltwell pumping of SSTs, line plugging has been evaluated in Kirch 1999.

For 242-A Evaporator slurry, transfer line plugging is addressed in the process control plan for each campaign.

For other waste streams where it is planned or suspected that solids will be entrained in or formed during transfer, an analysis of the system flow conditions must be performed to assess a probability that line plugging can be avoided. This will be accomplished by obtaining and/or analyzing the following parameters:

1. The expected carrier liquid density

2. The expected particulate solids density

3. The expected slurry density during transfer

4. The anticipated system flow rate

5. The particle size mass distribution or some other analytical measure such as the unhindered solids settling velocity from which an effective particulate solid diameter or diameter distribution can be obtained.

6. The expected carrier liquid viscosity or some other analytical measure such as the maximum expected slurry temperature during transfer from which the carrier liquid viscosity can be determined.

\subsubsection{Basis}

The basis for the line plugging decision rule is documented in Estey 1998. 


\subsection{WASTE SEGREGATION}

\subsubsection{Waste Segregation}

To the extent practicable, complexed wastes shall be segregated from non-complexed wastes in the DST system. However, if complexed waste is to be commingled with non-complexed waste, evaluate waste volume reduction effects of mixing. Complexed status of a waste is determined by one of the following methods:

- Use of the PREDICT model (Allison 1984) to estimate TOC concentration at DSSF composition showing $[\mathrm{TOC}] \leq 10 \mathrm{~g} / \mathrm{L}$ indicates that the waste is non-complexed.

- If concentration of the waste exhibits a rapid viscosity increase upon crystallization or the formation of small non-settling crystals the waste is complexed.

- Complexed status of DST wastes may be obtained from the most recent DST Waste Inventory from Process Engineering, Models and Inventory.

- Complexed status of SST wastes may be obtained from the most recent Waste Tank Summary Report (HNF-EP-0182-XXX).

To the extent practicable, complexed wastes shall be segregated from transuranic (TRU) wastes in the DST system. However, if complexed waste is to be commingled with TRU waste, evaluate whether additional TRU waste will be created as a result.

- TRU wastes contain a TRU concentration $\geq 100 \eta \mathrm{Ci} / \mathrm{g}$ at time of analysis.

To the extent practicable, TRU wastes shall be segregated from non-TRU wastes in the DST system. However, if TRU waste is to be commingled with non-TRU waste, evaluate whether additional TRU waste will be created as a result.

\subsubsection{Basis}

Segregation of complexed wastes enables them to be stored with a high water content, nominally $>50 \%$ water. A complexed waste is concentrated only to the saturation level of the major soluble salt (normally a nitrate), and formation of solid crystals is avoided. When complexed waste is concentrated it exhibits a rapid viscosity increase upon crystallization or formation of small non-settling crystals upon

concentration. A thick gel-like waste matrix with the consistency of petroleum jelly may be formed.

Although ORP has acknowledged that in-tank TRU waste can be adequately managed under the HighLevel Waste provisions of DOE Order 5820.2A, efforts are maintained to avoid forming organic-TRU complexes in the liquid phase. Dissolving precipitated TRU constituents increases the mobility of TRU in the DST system. 


\subsection{REFERENCES}

Adams, M. R., 1999, Tank waste Remediation System Process Engineering Instruction Manual, HNF-SDWM-PROC-021, Rev. 2-C, Lockheed Martin Hanford Corp., Richland, Washington.

Allison, J. M., 1984, Computer Prediction of Evaporator Operation, SD-WM-ADP-004, Rev. 0, Rockwell Hanford Operations, Richland, Washington.

Banning, D. L., Data Quality Objectives for TWRS Privatization Phase 1: Tank Waste Transfer Control, HNF-1802, Rev. 1, Lockheed Martin Hanford Corp., Richland, Washington.

Bratzel, D. R., W. W. Schulz, and R. Vornehm, 1996, Tank Farm Nuclear Criticality Review, WHC-SD-WM-TI-725, Rev. 0, Westinghouse Hanford Company, Richland, Washington.

Cox, W., L. Coleman, J. Colgan, B. Crea, P. Powell and R. Webb, 1997, Tank Farms Operations Administrative Controls, HNF-IP-1266, Rev. 1, Fluor Daniel Hanford, Inc., Richland, Washington.

Estey, S. D., and T. A. Hu, 1998, Flow Velocity Analysis for Avoidance of Solids Deposition During Transport of Hanford Tank waste Slurries, HNF-2728, Rev. 0, Lockheed Martin Hanford Corp., Richland, Washington.

Hedengren, D. C., J. D. Bingham, S. A. Barker, J. M. Conner, and S. D. Estey, 1997, Calculation of Flammable Gas Mixtures in Double Contained receiver Tanks, HNF-SD-WM-CN-118, Rev. 0, Lockheed Martin Hanford Corp., Richland, Washington.

Herting, D. L., 1987, "Phosphate Solubility in Simulated Defense Waste," Internal Memo, Rockwell Hanford Operations, March 6, 1987, Richland, Washington.

Herting, D. L., and K. J, Patterson, 1982, "Effects of Mixing Waste Types - Concentrated Streams," Internal Memo, Rockwell Hanford Operations, August 26, 1982, Richland, Washington.

Hu, T. A., 1997, Calculations of Hydrogen Release Rate at Steady State for Double-Shell Tanks, HNFSD-WM-CN-117, Rev. 0-A, Lockheed Martin Hanford Corp., Richland, Washington.

Kinzer, J. E., 1998, Contract Number DE-AC06-96RL13200 - Tank Waste Remediation System (TWRS) Cessation of Segregation of Complexed Waste from Non-Complexed Waste in Hanford High-Level Waste Tanks (HLW), Correspondence No. 9859695, to R. D. Hanson, dated November 5, 1998.

Kirch, N. W., 1999, “Technical Basis For When To Dilute Waste During Pumping,” Interoffice Memo \#74B50-99-004, to M. R. Koch, dated February 1, 1999, Lockheed Martin Hanford Corp., Richland, Washington.

LMHC, 2000a, Operating Specification for Watch List Tanks, OSD-T-151-00030, Rev. C-1, Lockheed Martin Hanford Corp., Richland, Washington. 
LMHC, 2000b, Operating Specifications for 24l-AN, AP, AW, AY, AZ, \& SY Tank Farms, OSD-T-15100007, Rev. H-22, Lockheed Martin Hanford Corp., Richland, Washington.

LMHC, 2000c, Operating Specifications for the 204-AR Waste Unloading Facility, OSD-T-151-00008, Rev. E-4, Lockheed Martin Hanford Corp., Richland, Washington.

LMHC, 2000d, Operating Specifications for Aging-Waste Operations in 241-AY and 241-AZ, OSD-T151-00017, Rev. D-12, Lockheed Martin Hanford Corp., Richland, Washington.

LMHC, 1998a, Criticality Prevention Specification, CPS-T-149-00010, Rev. I-0, Lockheed Martin Hanford Corp., Richland, Washington.

LMHC, 1998b, Administration: DST Waste Inventory Control Charter, HNF-IP-0842, Volume I, Section 3.12, Rev. 2a, Lockheed Martin Hanford Corp., Richland, Washington.

LMHC, 1996, Operating Specifications for the Saltwell Receiver Vessels, OSD-T-151-00011, Rev. C-5, Lockheed Martin Hanford Corp., Richland, Washington.

Meacham, J. E., 1998, Organic Complexant Topical Report, HNF-3588, Rev. 0, DE\&S, Hanford Inc., Richland, Washington.

Mulkey, C. H., L. P. Jackson and M. S. Miller, 1999, Data Quality Objectives for Tank Farms Waste Compatibility Program, HNF-SD-WM-DQO-001, Rev. 3, Lockheed Martin Hanford Corp., Richland, Washington.

Mulkey, C. H., 1998, Double-Shell Tank System Waste Analysis Plan, HNF-SD-WM-EV-053, Rev. 5, Lockheed Martin Hanford Corp., Richland, Washington.

Reynolds, D. A., 1994, Evaluation of Specific Gravity versus Gas Retention, Internal Memo \#7E310-94024, to N. W. Kirch, dated June 20, 1994.

Rogers, C. A., 1994, CSER 94-004: Criticality Safety of Double-Shell Waste Storage Tanks, WHC-SD-SQA-CSA-20368, Westinghouse Hanford Company, Richland, Washington.

USEPA, 1994, Waste Analysis at Facilities that Generate, Treat, Store, and Dispose of Hazardous Wastes: A Guidance Manual, PB94-963603, OSWER, 9938.4-03.

Wood, R. F., 2000, Restrictions on Double-Shell Tank Waste Receipts, Letter \#CHG-0003177, to J. L. Jacobsen, dated June 13, 2000. 
HNF-SD-WM-OCD-015, Rev. 3

\section{APPENDIX A}

\begin{tabular}{|c|c|c|}
\hline \multicolumn{3}{|c|}{$\begin{array}{l}\text { WASTE COMPATIBILITY COMPLIANCE TABLE } \\
\text { Source Waste with Receiver Tank Waste }\end{array}$} \\
\hline CRITERIA & PROGRAM REQUIREMENT & $\begin{array}{l}\text { COMPLIANCE } \\
\text { STATUS }\end{array}$ \\
\hline \multicolumn{3}{|c|}{ AUTHORIZATION BASIS CRITERIA } \\
\hline $\begin{array}{l}\text { Criticality } \\
\text { (Pu = plutonium equivalent) }\end{array}$ & $\begin{array}{l}\text { Source } \mathrm{Pu} \leq 0.001 \mathrm{~g} / \mathrm{l}, \mathrm{pH} \geq 8 \text {, or } \\
0.001 \mathrm{~g} / 1<\mathrm{Pu}<0.033 \mathrm{~g} / \mathrm{l}, \mathrm{pH} \geq 8 \text {, and at least one } \mathrm{X} / \mathrm{Pu}>\text { the corresponding } \\
\text { ratio in } \mathrm{HNF}-\mathrm{SD}-\mathrm{WM}-\mathrm{OCD}-015 \text {, Table } 2-1 \\
\text { If Pu content }>50 \mathrm{~g} \text { in a single batch, sum of component subcritical mass } \\
\text { fractions } \geq 2 \\
\text { 242-A Evaporator feed } \mathrm{Pu}<0.005 \mathrm{~g} / 1\end{array}$ & \\
\hline \multicolumn{3}{|l|}{ Disposition: } \\
\hline $\begin{array}{l}\text { Radiological Source Term Controls - } \\
\text { Contribution to ULD for Inhalation }\end{array}$ & $\begin{array}{l}\text { Non-tank farm facility waste: } \\
\mathrm{Sr}^{90}<27.77 \% \text { of ULD, } \\
\mathrm{Y}^{90}<0.97 \% \text { of ULD, } \\
\mathrm{Cs}^{137}<45.18 \% \text { of ULD, } \\
\mathrm{Pu}^{239}<12.41 \% \text { of ULD, } \\
\mathrm{Am}^{241}<11.78 \% \text { of ULD. } \\
\text { If one parameter exceeds specified ULD \%, then total of ULDs must } \\
\text { be }<98.11 \% \text {. }\end{array}$ & \\
\hline \multicolumn{3}{|l|}{ Disposition: } \\
\hline $\begin{array}{l}\text { Radiological Source Term Controls - } \\
\text { Contribution to ULD for Ingestion, } \\
\text { Ground Shine, and Resuspension }\end{array}$ & $\begin{array}{l}\text { Non-tank farm facility waste: } \\
\mathrm{Sr}^{90}<15.60 \% \text { of ULD, } \\
\mathrm{Y}^{90}<1.42 \% \text { of ULD, } \\
\mathrm{Cs}^{137}<82.68 \% \text { of ULD, } \\
\mathrm{Pu}^{239}<0.13 \% \text { of ULD, } \\
\mathrm{Am}^{241}<0.12 \% \text { of ULD. } \\
\text { If one parameter exceeds specified ULD \%, then total of ULDs must be }< \\
99.98 \%\end{array}$ & \\
\hline \multicolumn{3}{|l|}{ Disposition: } \\
\hline Toxic Chemical Source Term Controls & $\begin{array}{l}\text { Non-tank farm facility waste: } \\
\mathrm{NH}_{3}^{-}<4.78 \% \text { of Total Fraction of Risk Guide (TFRG), } \\
\mathrm{NaOH}<32.44 \% \text { of TFRG, } \\
\mathrm{Na}^{+}<54.07 \% \text { of TFRG, } \\
\mathrm{TOC}^{- \text {Oxalate }}<4.05 \% \text { of TFRG, } \\
\mathrm{U}<3.33 \% \text { of TFRG. } \\
\text { If one parameter exceeds specified TFRG } \% \text {, then total of TFRGs must be } \\
<98.67 \%\end{array}$ & \\
\hline \multicolumn{3}{|l|}{ Disposition: } \\
\hline Bulk Chemical Runaway Reaction & $\begin{array}{l}\text { Receiving tank end state heat load }<74,000 \mathrm{Btu} / \mathrm{hr} \text { and } \mathrm{TOC}<52 \mathrm{~g} / 1(3.8 \mathrm{wt} \%) \\
\qquad \mathrm{OR} \\
\text { If further evaluation per method in HNF-3588 determines that a bulk chemical } \\
\text { runaway is not possible }\end{array}$ & \\
\hline Dispositic & & \\
\hline
\end{tabular}




\begin{tabular}{|c|c|c|}
\hline \multicolumn{3}{|c|}{$\begin{array}{l}\text { WASTE COMPATIBILITY COMPLIANCE TABLE } \\
\text { Source Waste with Receiver Tank Waste }\end{array}$} \\
\hline CRITERIA & PROGRAM REQUIREMENT & $\begin{array}{l}\text { COMPLIANCE } \\
\text { STATUS }\end{array}$ \\
\hline Tank Time to LFL Determination & $\begin{array}{l}\text { DST and AWF: minimum time to reach } 25 \% \text { of LFL for tank vapor space will } \\
\text { remain } z 7 \text { days, assuming loss of primary tank ventilation. } \\
\text { DCRT: DCRT vapor space will remain } s 25 \% \text { of the LFL. }\end{array}$ & \\
\hline \multicolumn{3}{|l|}{ Disposition: } \\
\hline \multicolumn{3}{|c|}{ SAFETY CRITERIA } \\
\hline Flammable Gas & $\begin{array}{l}\text { Source \& receiver tank } \\
\text { (Solids depth (in.) } x \mathrm{nc} \mathrm{SpG} \text { ) }<148 \\
\text { If source waste } \mathrm{SpG}>1.41 \text {, receiver tank average } \mathrm{SpG}_{\leq} 1.41 \text { after transfer }\end{array}$ & \\
\hline \multicolumn{3}{|l|}{ Disposition: } \\
\hline Organic and Energetic Reaction & $\begin{array}{l}\text { Source Exotherm/Endotherm }<1.0 ; \text { No separable organic layer } \\
\text { Maximum Exotherm }=480 \text { joules/gram } \\
\text { If free water }<20 \% \text {, TOC (dry) }<4.5+0.17 \text { (wt } \% \text { free water) }\end{array}$ & \\
\hline \multicolumn{3}{|l|}{ Disposition: } \\
\hline Corrosion Control & 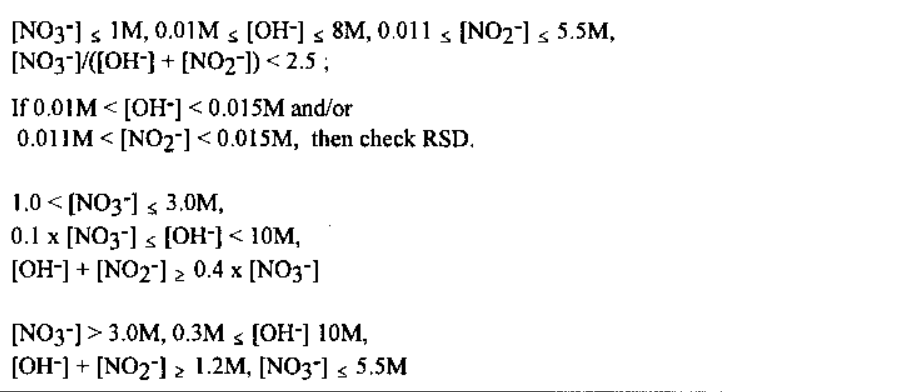 & \\
\hline \multicolumn{3}{|l|}{ Disposition: } \\
\hline Watch List Tanks & $\begin{array}{l}\text { Transfer of waste out of a flammable gas Watch List DST requires written } \\
\text { approval } \\
\text { Transfer of waste out of an organic Watch List DST requires written approval } \\
\text { by ORP }\end{array}$ & \\
\hline \multicolumn{3}{|l|}{ Disposition: } \\
\hline \multicolumn{3}{|c|}{ REGULATORY CRITERIA } \\
\hline Current WSPS & $\begin{array}{l}\text { Source Waste from outside the DST System must have a current } \\
\text { WSPS on file. } \\
\text { New/Revised WSPS reviewed by CSR/Alternate } \\
\text { (Non-Tank Farms facility waste streams only) }\end{array}$ & \\
\hline \multicolumn{3}{|l|}{ Disposition: } \\
\hline Chemical Compatibility & $\begin{array}{l}\text { Identify potential hazards for mixing wastes in specific reactivity } \\
\text { groups (HNF-SD-WM-OCD-015, Fig. 4-1) }\end{array}$ & \\
\hline
\end{tabular}




\section{WASTE COMPATIBILITY COMPLIANCE TABLE Source Waste with Receiver Tank Waste}

\section{CRITERIA \\ PROGRAM REQUIREMENT}

COMPLIANCE STATUS

Disposition:

Interim PCB Management

No external wastes containing PCBs allowed and only $222-\mathrm{S}$ or $325 \mathrm{Lab}$ waste allowed provided PCB concentration in waste is less than or equal to $45 \mathrm{ppm}$ in solids and $200 \mathrm{ppb}$ in liquid phase. Otherwise, ORP approval is required.

Disposition:

\section{PROGRAMMATIC CRITERIA}

Configuration Control

Maintain transfers consistent with restrictions given in HNF-1802, "DQO for TWRS Privatization Phase 1"

Disposition:

Waste Feed Envelope

Envelope A:

$<0.5$ moles of organic carbon per mole of sodium;

$<4.4 \mathrm{E} 7$ Becquerels $(\mathrm{Bq}) \mathrm{St}^{\text {\%) }}$ per mole sodium;

$<4.8$ E5 Bq TRU per mole sodium;

Complexed concentrate $(\mathrm{CC})$ stored with other $\mathrm{CC}$ waste.

Disposition:

WIC Group Review/Approval All waste transfers require WIC Group review/approval.

Disposition:

\section{OPERATIONAL CRITERIA}

Heat Generation Rate

AN, AP \& AW tanks $\leq 70,000 \mathrm{Btu} / \mathrm{hr}$;

$\mathrm{SY}$ tanks $\leq 50,000 \mathrm{Btu} / \mathrm{hr}$

$\mathrm{AY} \& \mathrm{AZ}$ tanks $\leq 4,000,000 \mathrm{Btu} / \mathrm{hr}$.

Disposition:

AWF 5 Molar Sodium Rule

Max. $\left[\mathrm{Na}^{+}\right]=5.0 \mathrm{M}$ in AWF tanks

Disposition:

Phosphate Waste

High phosphate waste $\left(\left[\mathrm{PO}_{4}^{-3}\right]>0.1 \mathrm{M}\right)$ not to be mixed with high salt waste $\left(\left[\mathrm{Na}^{+}\right]>8.0 \mathrm{M}\right)$.

Disposition:

Line Plugging $<5$ volume $\%$ solids and $\mathrm{SpG}_{\leq} 1.35$ or evaluation necessary

Disposition:

Waste Segregation

Segregate complexed and TRU wastes to minimize creation of additional TRU waste and minimize adverse impacts to waste volume reduction

Disposition: 


\section{APPENDIX B}

Tank Farms Compatibility Program Analytes and Requirements Summary

\begin{tabular}{|c|c|c|}
\hline Analyte & Tank Farm Waste Requirement & Non-Tank Farm Waste Requirement \\
\hline $\mathrm{Pu}^{239}$ & $\begin{array}{l}\text { Feed Env. (if no TA) } \\
\text { Segregation (if no TA) } \\
\text { Inventory }\end{array}$ & $\begin{array}{l}\text { Crit.; ULD } \\
\text { Segregation }\end{array}$ \\
\hline $\mathrm{U}^{233}$ & Inventory (if no Total U) & Crit. \\
\hline $\mathrm{U}^{235}$ & Inventory (if no Total U) & Crit. \\
\hline Total U & Inventory (If no $U^{233}$ and $U^{235}$ ) & $\begin{array}{l}\text { TFRG, } \\
\text { absorber ratio if } \mathrm{Pu}>.001 \mathrm{~g} / \mathrm{l}\end{array}$ \\
\hline $\mathrm{Sr}^{90}$ & $\begin{array}{l}\text { Heat load (DST TT LFL) } \\
\text { Feed Env. }\end{array}$ & $\begin{array}{l}\text { 7.1.1.1.1 ULD; Feed Env. } \\
\text { Heat load (DST TT LFL) }\end{array}$ \\
\hline $\mathrm{Cs}^{137}$ & Heat load (DST TT LFL) & $\begin{array}{l}\text { 7.1.1.1.2 ULD } \\
\text { Heat load (DST TT LFL) }\end{array}$ \\
\hline $\mathrm{Am}^{241}$ & $\begin{array}{l}\text { Feed Env. (if no TA) } \\
\text { Segregation (if no TA) }\end{array}$ & $\begin{array}{l}\text { ULD } \\
\text { Segregation }\end{array}$ \\
\hline $\mathrm{NH}_{3}$ & DCRT \%LFL (if through DCRT) & $\begin{array}{l}\text { TFRG } \\
\text { DCRT \%LFL (if through DCRT) }\end{array}$ \\
\hline $\mathrm{NaOH}$ & None & TFRG \\
\hline $\mathrm{Na}$ & $\begin{array}{l}\text { Feed Env. } \\
\text { Phosphate Rule } \\
\text { AWF transfers }\end{array}$ & $\begin{array}{l}\text { TFRG; Feed Env. } \\
\text { Phosphate Rule } \\
\text { AWF transfers }\end{array}$ \\
\hline TOC & $\begin{array}{l}\text { DST TT LFL } \\
\text { Feed Env. }\end{array}$ & $\begin{array}{l}\text { TFRG; DST TT LFL } \\
\text { Feed Env. }\end{array}$ \\
\hline Oxalate & None & TFRG (subtract from TOC if necessary) \\
\hline $\mathrm{NO}_{2}$ & Corrosion; DST TT LFL & Corrosion; DST TT LFL \\
\hline $\mathrm{NO}_{3}$ & Corrosion; DST TT LFL & Corrosion; DST TT LFL \\
\hline $\mathrm{Al}$ & DST TT LFL & DST TT LFL \\
\hline $\mathrm{SpG}$ & $\begin{array}{l}\text { DST TT LFL } \\
\text { Flam Gas Retention }\end{array}$ & $\begin{array}{l}\text { DST TT LFL } \\
\text { Flam Gas Retention }\end{array}$ \\
\hline$\% \mathrm{H}_{2} \mathrm{O}$ & DST TT LFL & DST TT LFL \\
\hline DSC & Energetics Screen & Energetics Screen \\
\hline Separable Organic & Organic Screen & Organic Screen \\
\hline $\mathrm{OH}$ & Corrosion & Corrosion \\
\hline $\mathrm{pH}$ & None & Crit. \\
\hline
\end{tabular}


HNF-SD-WM-OCD-015, Rev. 3

\begin{tabular}{|l|l|l|}
\hline \multicolumn{3}{|c|}{ Tank Farms Compatibility Program Analytes and Requirements Summary } \\
\hline \multicolumn{1}{|c|}{ Analyte } & \multicolumn{1}{|c|}{ Tank Farm Waste Requirement } & Non-Tank Farm Waste Requirement \\
\hline Total Alpha (TA) & $\begin{array}{l}\text { Feed Env. (if no } \mathrm{Am}^{241}, \mathrm{Pu}^{239} \text { ) } \\
\text { Segregation (if no } \mathrm{Am}^{241}, \mathrm{Pu}^{239} \text { ) }\end{array}$ & Feed Env. \\
\hline $\mathrm{PO}_{4}$ & $\begin{array}{l}\text { Phosphate Rule } \\
\text { PREDICT input (if needed) }\end{array}$ & $\begin{array}{l}\text { Phosphate Rule } \\
\text { PREDICT input (if needed) }\end{array}$ \\
\hline $\mathrm{F}$ & PREDICT input (if needed) & PREDICT input (if needed) \\
\hline $\mathrm{SO}_{4}$ & PREDICT input (if needed) & PREDICT input (if needed) \\
\hline $\mathrm{Cl}$ & None & Corrosion (through 204-AR) \\
\hline $\mathrm{Cr}$ & None & Absorber Ratio (if $\mathrm{Pu}>.001 \mathrm{~g} / \mathrm{l})$ \\
\hline $\mathrm{Fe}$ & None & Absorber Ratio (if $\mathrm{Pu}>.001 \mathrm{~g} / \mathrm{l})$ \\
\hline $\mathrm{Ni}$ & None & Absorber Ratio (if $\mathrm{Pu}>.001 \mathrm{~g} / \mathrm{l})$ \\
\hline $\mathrm{Mn}$ & None & Absorber Ratio (if $\mathrm{Pu}>.001 \mathrm{~g} / \mathrm{l})$ \\
\hline
\end{tabular}

$\mathrm{TT}$ LFL = time to LFL determination 


\begin{tabular}{|c|c|c|c|c|c|}
\hline \multicolumn{6}{|c|}{ DISTRIBUTION SHEET } \\
\hline To & \multirow{2}{*}{$\begin{array}{l}\text { From } \\
\text { Process Control }\end{array}$} & & \multicolumn{3}{|c|}{ Page 1 of 1} \\
\hline Distribution & & & & \multicolumn{2}{|c|}{ Date $7 / 12 / 100$} \\
\hline \multirow{2}{*}{\multicolumn{3}{|c|}{$\begin{array}{l}\text { Project Title/Work Order } \\
\text { Tank Farm Waste Transfer Compatibility Program }\end{array}$}} & \multicolumn{3}{|c|}{ EDT No. NA } \\
\hline & & & \multicolumn{3}{|c|}{ ECN No. 657005} \\
\hline Name & MSIN & $\begin{array}{c}\text { Text } \\
\text { With All } \\
\text { Attach. }\end{array}$ & $\begin{array}{l}\text { Text } \\
\text { Only }\end{array}$ & $\begin{array}{c}\text { Attach. } \\
\text { Appendix } \\
\text { Only }\end{array}$ & $\begin{array}{c}\mathrm{EDT} / \mathrm{ECN} \\
\text { Only }\end{array}$ \\
\hline \multicolumn{6}{|c|}{ CH2M HILL Hanford Group, Inc. } \\
\hline D. G. Baide & S5-05 & $\mathrm{X}$ & & & \\
\hline T. M. Blaak & S5-13 & $\mathrm{X}$ & & & \\
\hline V. C. Boyles & R2-11 & $\mathrm{X}$ & & & \\
\hline M. L. Dexter & R1-51 & $\mathrm{X}$ & & & \\
\hline J. N. Doeler & T4-07 & $\mathrm{X}$ & & & \\
\hline J. G. Field & $\mathrm{R} 2-12$ & $\mathrm{X}$ & & & \\
\hline L. A. Fort & $\mathrm{R} 2-12$ & $\mathrm{X}$ & & & \\
\hline K. D. Fowler (10) & R2-11 & $\mathrm{X}$ & & & \\
\hline K. M. Hodgson & $\mathrm{R} 2-11$ & $\mathrm{X}$ & & & \\
\hline T. A. Hu & R2-11 & $\mathrm{X}$ & & & \\
\hline J. W. Hunt & $\mathrm{R} 2-12$ & $\mathrm{X}$ & & & \\
\hline J. Jo & R3-73 & $\mathrm{X}$ & & & \\
\hline C. E. Leach & R1-44 & $\mathrm{X}$ & & & \\
\hline J. A. Lechelt & R2-11 & $\mathrm{X}$ & & & \\
\hline N. W. Kirch & $\mathrm{R} 2-11$ & $\mathrm{X}$ & & & \\
\hline R. E. Larson & T4-07 & $\mathrm{X}$ & & & \\
\hline C. H. Mulkey & $\mathrm{R} 1-51$ & $\mathrm{X}$ & & & \\
\hline P. A. Powell & R1-51 & $\mathrm{X}$ & & & \\
\hline W. E. Ross & $\mathrm{R} 2-50$ & $\mathrm{X}$ & & & \\
\hline L. M. Sasaki & $\mathrm{R} 2-12$ & $\mathrm{X}$ & & & \\
\hline J. N. Strode & R2-11 & $\mathrm{X}$ & & & \\
\hline M. J. Sutey & S5-07 & $\mathrm{X}$ & & & \\
\hline L. E. Thomas & S7-01 & $\mathrm{X}$ & & & \\
\hline E. V. Weiss & $\mathrm{R} 2-12$ & $\mathrm{X}$ & & & \\
\hline TCSRC & $\mathrm{R} 1-10$ & $\mathrm{X}$ & & & \\
\hline $\begin{array}{l}\text { Lockheed Martin Servic } \\
\text { Central Files }\end{array}$ & B1-07 & $\mathrm{X}$ & & & \\
\hline
\end{tabular}

